Review

\title{
Non-Volatile Particle Number Emission Measurements with Catalytic Strippers: A Review
}

\author{
Barouch Giechaskiel *, Anastasios D. Melas ${ }^{\circledR}$, Tero Lähde and Giorgio Martini \\ European Commission—Joint Research Centre (JRC), 21027 Ispra, Italy; anastasios.melas@ec.europa.eu (A.D.M.); \\ tero.lahde@ec.europa.eu (T.L.); giorgio.martini@ec.europa.eu (G.M.) \\ * Correspondence: barouch.giechaskiel@ec.europa.eu; Tel.: +39-0332-78-5312
}

Received: 21 May 2020; Accepted: 23 June 2020; Published: 24 June 2020

\begin{abstract}
Vehicle regulations include limits for non-volatile particle number emissions with sizes larger than $23 \mathrm{~nm}$. The measurements are conducted with systems that remove the volatile particles by means of dilution and heating. Recently, the option of measuring from $10 \mathrm{~nm}$ was included in the Global Technical Regulation (GTR 15) as an additional option to the current $>23 \mathrm{~nm}$ methodology. In order to avoid artefacts, i.e., measuring volatile particles that have nucleated downstream of the evaporation tube, a heated oxidation catalyst (i.e., catalytic stripper) is required. This review summarizes the studies with laboratory aerosols that assessed the volatile removal efficiency of evaporation tube and catalytic stripper-based systems using hydrocarbons, sulfuric acid, mixture of them, and ammonium sulfate. Special emphasis was given to distinguish between artefacts that happened in the 10-23 nm range or below. Furthermore, studies with vehicles' aerosols that reported artefacts were collected to estimate critical concentration levels of volatiles. Maximum expected levels of volatiles for mopeds, motorcycles, light-duty and heavy-duty vehicles were also summarized. Both laboratory and vehicle studies confirmed the superiority of catalytic strippers in avoiding artefacts. Open issues that need attention are the sulfur storage capacity and the standardization of technical requirements for catalytic strippers.
\end{abstract}

Keywords: vehicle emissions; particle measurement programme (PMP); portable emissions measurement systems (PEMS); volatile removal efficiency; non-volatiles; solid particle number; catalytic stripper; evaporation tube; artefact

\section{Introduction}

In order to reduce pollution from particulate matter (PM), limits for the PM mass emissions of vehicles are applicable in most countries worldwide [1]. The engine and aftertreatment improvements reduced the emitted PM levels close to the detection limit of the PM methodology [2]. In order to further control the emissions of ultrafine particles, which do not contribute significantly to the PM mass, the European Union (EU) regulations included limits for the non-volatile particle emissions of light-duty, heavy-duty, and non-road mobile machinery since 2011-2013 [3,4].

The particle number methodology is based on sampling from a dilution tunnel where the whole exhaust gas is mixed with ambient air dilution air. In order to measure only non-volatile particles, the sample is pre-conditioned first in a hot diluter at $150{ }^{\circ} \mathrm{C}$ and then in an evaporation tube at $350^{\circ} \mathrm{C}$, the so called volatile particle remover $[5,6]$. After a secondary dilution at ambient temperature, a particle number counter (PNC) counts all (non-volatile) particles above $23 \mathrm{~nm}$. In reality the detection efficiency of the PNC, typically a condensation particle counter (CPC), is around $50 \%$ at $23 \mathrm{~nm},>90 \%$ at $41 \mathrm{~nm}$ and $0 \%$ at $17 \mathrm{~nm}$. The $23 \mathrm{~nm}$ cut-off size was selected in order to include the smallest primary soot particles, and exclude the volatile nucleation mode particles that could survive the pre-conditioning unit. The methodology was extended, but more simplified, to measure directly from 
the tailpipe during on-road tests with the real-driving emissions (RDE) regulation for both light-duty and heavy-duty vehicles [7]. The portable emissions measurement systems (PEMS) set the volatile particle remover at $300^{\circ} \mathrm{C}$, in order to reduce energy consumption. From the controlled laboratory environment, the measurements can take place under any environmental and driving conditions, thus the measurement equipment can be challenged. Indeed, the survival of volatile particles through the thermal pre-conditioning unit or formation of volatile particles after the unit can lead to false high concentrations of volatiles that will be counted as non-volatile particles. This was quite unlikely with the $23 \mathrm{~nm}$ cut-off size of the PNC, but has happened in the sub-23 $\mathrm{nm}$ range [8,9], raising concerns as to whether the methodology should be extended below $23 \mathrm{~nm}$.

On the other hand, a major criticism of the particle number methodology is that it excludes an important fraction of non-volatile particles below $23 \mathrm{~nm}$ that are emitted by many vehicle technologies [10]. For example, sub-23 nm non-volatile particles have been reported for heavy-duty vehicles [11], especially during urea injection [12], gasoline fueled vehicles [13], both port-fuel and direct injection vehicles. Recently, concerns for CNG (compressed natural gas) fueled vehicles were also raised [3,12]. Mopeds and motorcycles have also a high percentage of sub-23 nm particles. For this reason, the intention is to extend the methodology to include particles from approximately $10 \mathrm{~nm}$. The $10 \mathrm{~nm}$ size was selected in order to permit the upgrade of existing PN systems without investment costs and to minimize the higher risk of surviving (or re-nucleating) volatile particles [14]. Furthermore, it will be suitable for the upgrade of the current $23 \mathrm{~nm}$ PEMS [15,16]. Developing a methodology to count smaller than $10 \mathrm{~nm}$ particles would be extremely challenging due to the uncertainties related to particle losses and calibration procedures.

A proposed methodology to eliminate the volatiles and make the methodology more robust is the catalytic stripper [17]. The idea is based on catalytic converters of vehicles, which remove hydrocarbons (in addition to $\mathrm{CO}$ and $\mathrm{NO}_{\mathrm{x}}$ ). Typically, they utilize a ceramic honeycomb monolithic substrate (support) with many small parallel channels. The monolith walls are coated with an active catalyst layer [18]. The catalytic coating includes noble metal catalysts (such as Pt and Pd) impregnated on a porous high surface area layer of inorganic carrier (support), the washcoat, such as alumina and silica. The support material often contains additives such as promoters and stabilizers. Based on $\mathrm{NO}_{\mathrm{x}}$ storage catalysts $[19,20]$, the catalytic strippers include sometimes a sulfur trap to further improve their removal efficiency of sulfuric acid containing aerosol. Catalytic strippers have been used not only in the automotive field [21], but also in the aviation field [22], and for atmospheric measurements [23].

Thermodenuders can also remove volatiles species from the exhaust gas [24,25]. In the thermodenuders, the sample is first heated in an evaporation tube, and then it passes through an unheated section containing adsorbing material, most often activated carbon, which adsorbs most of the evaporated components.

The objective of this study is to review the volatile removal efficiency and sulfur storage capacity of catalytic strippers and their suitability for inclusion in the particle number systems. The review results are compared with the current methodology that uses hot dilution and evaporation tube and with thermodenuders used in research. In order to put the results into the right context, actual volatile emission levels from vehicles are also summarized. Finally, recommendations for technical requirements for catalytic strippers are proposed.

\section{Materials and Methods}

This review focused on studies that characterized catalytic strippers and evaporation tubes as standalone systems or in volatile particle removers of particle number systems (i.e., downstream of a hot dilution at temperature $>150^{\circ} \mathrm{C}$ ). We searched in Google Scholar with keywords "catalytic stripper", "evaporation tube + particles" and "volatile removal efficiency". The search resulted in 533, 900 and 73 documents, respectively. From the abstracts it was decided whether the documents were relevant or not. The only acceptance criterion was the inclusion in the text of volatile removal efficiency with laboratory aerosols or vehicles' exhaust. Studies that used evaporation tubes or catalytic strippers 
for measurements of vehicle exhaust were excluded, unless there was discussion of possible artefacts, or comparisons between catalytic strippers and evaporation tubes on the removal of volatile particles. In total, 29 studies were selected, 18 used a laboratory aerosol, and 14 a vehicle's aerosol (3 were in common). Table 1 summarizes the studies included.

Table 1. Number of studies assessing evaporation tubes (ET), catalytic strippers (CS), or thermodenuders (TD). The laboratory studies were conducted with hydrocarbons (HCs) and/or sulfuric acid $\left(\mathrm{H}_{2} \mathrm{SO}_{4}\right)$. In brackets the studies using CS with sulfur trap.

\begin{tabular}{cccc}
\hline System & Laboratory HCs & Laboratory $\mathbf{H}_{\mathbf{2}} \mathbf{S O}_{\mathbf{4}}$ & Vehicles' Aerosol \\
\hline ET & 13 & 6 & 14 \\
CS & $15(9)$ & $7(5)$ & $8(7)$ \\
CS vs. ET or TD & $10(6)$ & $6(4)$ & $8(7)$ \\
\hline
\end{tabular}

We used the same search engine for sulfur storage capacity of catalysts and $\mathrm{SO}_{2}$ to $\mathrm{SO}_{3}$ conversion rates. Keywords such as "sulfur trap", sulfur storage catalyst", "sulfur absorber", "sulfur poisoning" were used. Only key studies were used because the objective was to put the catalytic stripper assessment results into perspective (i.e., compare with automotive catalytic converters).

We also reviewed emission levels of volatile and semi-volatile components at the tailpipe of the vehicles or at the dilution tunnel. The focus was on two-stroke mopeds, motorcycles, gasoline and diesel light-duty and heavy-duty vehicles mainly of recent technologies. Special attention was paid to emission levels during the cold start of the engines, filter regenerations, or prolonged highway operation, where high levels of volatiles are expected. The search was narrowed to hydrocarbons, $\mathrm{SO}_{2}$, $\mathrm{SO}_{3}$ and $\mathrm{H}_{2} \mathrm{SO}_{4}$, which were the species that were used for the evaluation of the catalytic strippers and evaporation tubes. The research was not extensive, as the target was to find typical maximum levels that the particle number systems can be challenged.

\section{Results}

The particle number systems measure non-volatile particles $>23 \mathrm{~nm}$. Note that "solids" or "non-volatile" particles are by definition the particles that remain after thermal pre-treatment at $350{ }^{\circ} \mathrm{C}$ for a residence time of approximately $0.2-0.4 \mathrm{~s}$. The term "volatiles" in this text covers all species that are in gaseous state at temperatures below $350{ }^{\circ} \mathrm{C}$. More appropriate terms such as semi-volatile or intermediate volatility compounds will not be used [26].

\subsection{Volatile Particle Remover}

The particle number systems consist of a volatile particle remover (VPR) and a particle number counter (PNC). Figure 1 presents a volatile particle remover with an evaporation tube (upper panel) or a catalytic stripper (lower panel).

\subsubsection{Evaporation Tube-Based Systems}

The exhaust gas at the dilution tunnel is already diluted and cooled down to ambient temperature levels (usually between $20^{\circ} \mathrm{C}$ and $50^{\circ} \mathrm{C}$ ). The diluted aerosol typically consists of soot particles with some species condensed on them, volatile nucleation mode particles, and volatile species in the gas phase. The volatile particles contain high percentages of compounds such as organics and sulfuric acid [27]. The soot particles are aggregates consisting of primary soot particles having diameters between $20 \mathrm{~nm}$ and $30 \mathrm{~nm}$ [28]. The geometric mean diameter of the soot mode is around 50-70 $\mathrm{nm}$ [2], but for modern gasoline engines, means of around $30 \mathrm{~nm}$ have also been reported [4]. The nucleation mode size-range is usually below $20 \mathrm{~nm}$. 


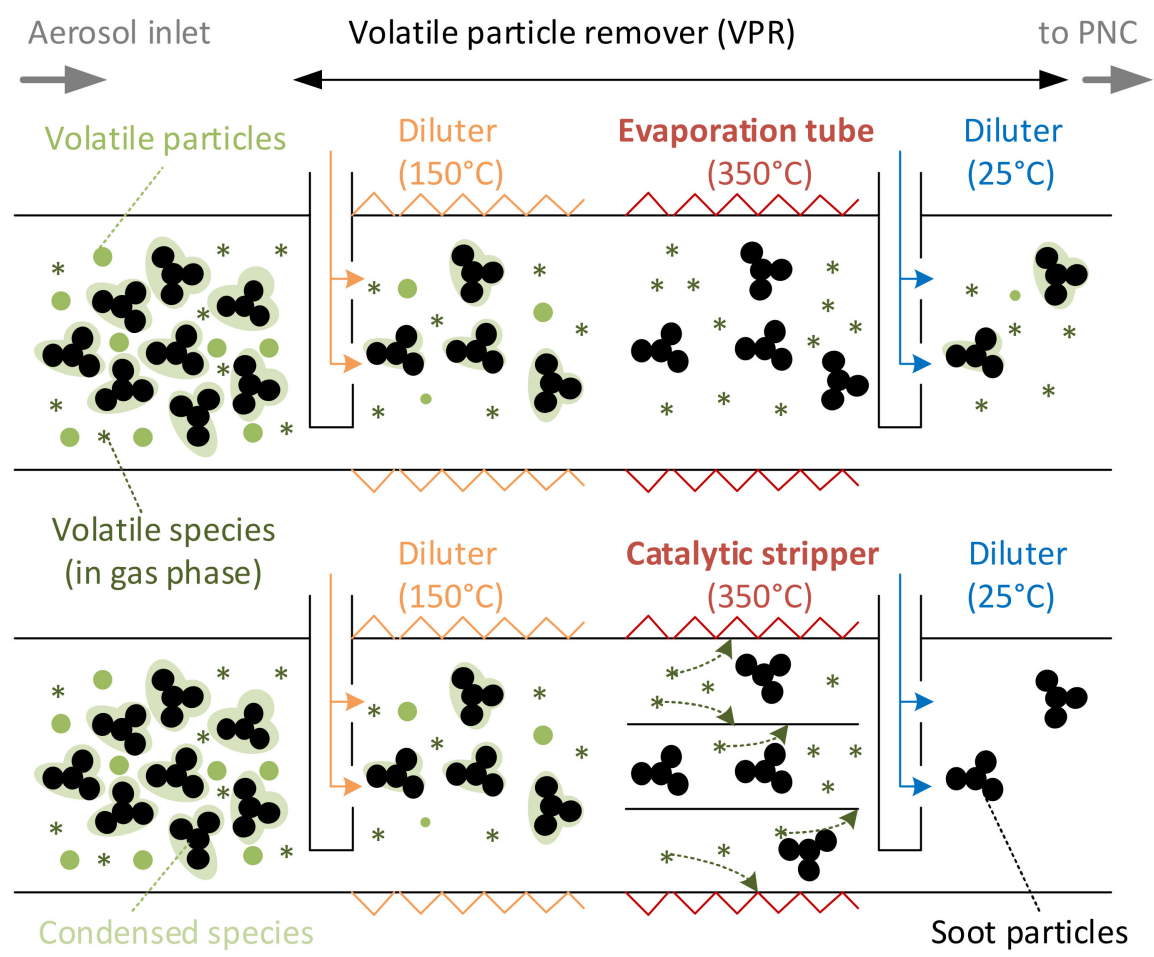

Figure 1. Schematic of volatile particle removers based on evaporation tube (upper panel) and catalytic stripper (lower panel). PNC = particle number counter.

In the primary hot diluter $\left(\geq 150^{\circ} \mathrm{C}\right)$ some of the condensed material evaporates and the nucleation mode particles evaporate and shrink. Furthermore, the concentration (and partial pressure) of the volatiles species decreases. In the evaporation tube $\left(350^{\circ} \mathrm{C}\right)$ most of the volatile particles and the condensed material evaporate. The cold diluter downstream of the evaporation tube further dilutes the sample to bring the temperature and the soot concentration to an appropriate range for the PNC. During this process it is possible to have re-condensation on the soot particles and/or re-nucleation of volatile species (i.e., formation of new volatile particles) especially if the dilution ratio is not sufficiently high. The nucleated particles due to the low concentrations of available species are unlikely to grow over $23 \mathrm{~nm}$ in diameter, and thus they will not be counted by the PNC, which has detection efficiency of $50 \%$ for particles of $23 \mathrm{~nm}$ diameter. The particles nucleated downstream of the evaporation tube and counted with a PNC are called volatile artefacts [14]. The next sections will summarize the studies that evaluated the concentration levels of volatile species that artefacts can be avoided.

\subsubsection{Catalytic Stripper-Based Systems}

When a catalytic stripper is used, instead (or in addition to) an evaporation tube, the volatile species in the gas phase are oxidized (Figure 1, lower panel). Then, during dilution and cooling at the secondary diluter the concentrations of nucleating species is too low to form volatile particles and, thus, the possibility for artefacts is minimized.

There are three types of catalytic strippers. Those that comprise:

- Only oxidation catalyst;

- Sulfur trap and oxidation catalyst (in this order);

- Oxidation catalyst and sulfur trap.

The first catalytic stripper for automotive use was mentioned in 1995 [17]. It was constructed from a commercial diesel oxidation catalyst (DOC) and operated at $300^{\circ} \mathrm{C}$. A cooling coil tube downstream of the catalytic stripper reduced the sample temperature to ambient levels. Optimization work in terms of particle losses and volatile removal efficiency was presented in 2007 [29]. In particular, a vortex 
tube diluter downstream of the catalytic stripper minimized thermophoretic losses. Later the catalytic stripper was installed in a particle number system compliant with the European regulations replacing the evaporation tube [30].

A catalytic stripper with an upstream sulfur trap was presented in 2003 [31]. The sulfur trap prevented poisoning of the oxidation catalyst by trapping the sulfur species and minimized artefacts from the nucleation of $\mathrm{SO}_{3}$. This concept was compared to a thermodenuder in 2010 [32]. Later the position of the sulfur trap was assessed at a different catalytic stripper and it was found to have higher sulfur storage capacity when placed downstream [33]. The majority of the catalytic strippers in the market for research or regulation purposes consist either only of an oxidation catalyst or oxidation catalyst with a sulfur trap downstream.

\subsection{Hydrocarbons}

Figure 2 summarizes the volatile removal efficiency of studies that used hydrocarbons (tetracosane C24, octacosane C28, tetracontane $\mathrm{C} 40$ and emery oil) for evaporation tube $[5,30,32,34-43]$ and catalytic stripper-based [30,32-41,44-47] systems. Each point is a test. The mass concentration of the challenge aerosol can be seen in the $y$-axis. The $x$-axis is divided in four areas which indicate whether no or some particles remained (or nucleated) downstream of the system under evaluation.

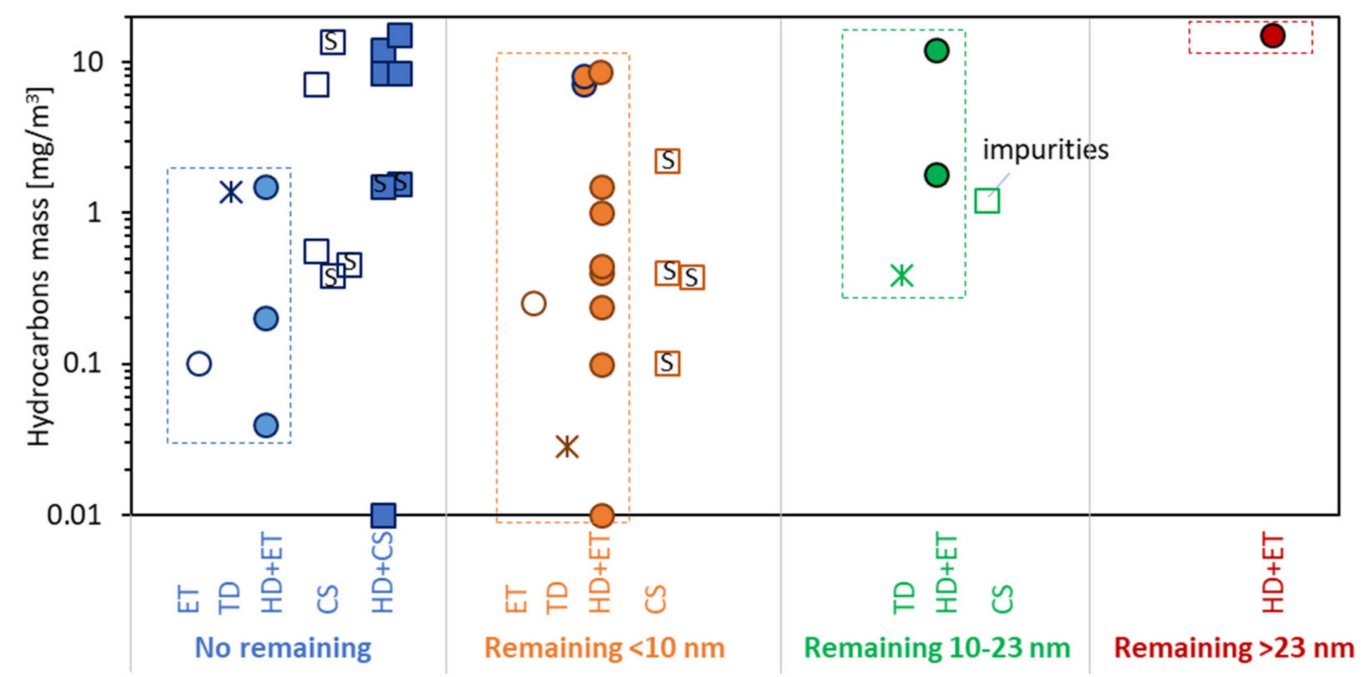

Figure 2. Volatile removal evaluation with hydrocarbons depending on whether none or some particles remained (or re-nucleated) $<10 \mathrm{~nm}$, between 10 and $23 \mathrm{~nm}$, and $>23 \mathrm{~nm}$. Open circles: evaporation tubes (ET); asterisks: thermodenuders (TD); solid circles: hot dilution and evaporation tubes (HD + ET); open squares: catalytic strippers (CS); solid squares: hot dilution and catalytic strippers (HD + CS). "S" indicates CS with sulfur trap.

- No particles remained downstream of the system under evaluation (blue color). Note that typically the lower detection size of these studies was around 3-6 nm.

- Particles with sizes lower than $10 \mathrm{~nm}$ were detected downstream of the system under evaluation (orange color). These cases are of low risk for the future $>10 \mathrm{~nm}$ regulation but could have artefacts with low cut-off counters.

- Particles in the size region 10-23 nm remained (green color). These cases are risky for the future $>10 \mathrm{~nm}$ regulation and indicate hydrocarbons mass levels that could lead to "volatile" artefacts.

- Particles larger than $23 \mathrm{~nm}$ were detected (red color). These cases would affect also the results of the current $>23 \mathrm{~nm}$ regulation. 
In each area the results are separately plotted for:

- $\quad$ Standalone evaporation tubes (ET) (open circles).

- $\quad$ Thermodenuders (TD) (asterisks).

- Hot dilution (typically 10:1) plus evaporation tubes (HD + ET) (solid circles).

- Standalone catalytic strippers (CS) (open squares).

- Hot dilution plus catalytic strippers (HD + CS) (solid squares).

For better clarity the evaporation tube (stand alone or downstream of a hot dilution) and thermodenuder tests are enclosed in dashed squares. Only the tests with the maximum reported concentrations in each study are plotted.

The hot dilution plus evaporation tube (HD + ET) results resulted in artefacts $>23 \mathrm{~nm}$ when challenged with $15 \mathrm{mg} / \mathrm{m}^{3}$ [34], while levels $2-12 \mathrm{mg} / \mathrm{m}^{3}$ had artefacts in the $10-23 \mathrm{~nm}$ range [36,39]. Artefacts $<10 \mathrm{~nm}$ were detected with masses in a wide range of $0.01 \mathrm{mg} / \mathrm{m}^{3}$ to $8.5 \mathrm{mg} / \mathrm{m}^{3}[5,30,32,36,37,39-41]$. On the other hand, no artefacts were seen with masses up to $1.5 \mathrm{mg} / \mathrm{m}^{3}$ for the combination of hot dilution and evaporation tube [43], confirming that the results might be system dependent. Standalone evaporation tubes (ET) could have artefacts $<10 \mathrm{~nm}$ already at low levels $\left(0.25 \mathrm{mg} / \mathrm{m}^{3}\right)$ [5].

The catalytic stripper systems had no artefacts above $10 \mathrm{~nm}$, with one exception which was probably solid residuals from impurities in the atomized material $[45,48]$. Masses up to $2 \mathrm{mg} / \mathrm{m}^{3}$ resulted in some particles remaining $<10 \mathrm{~nm}$ for some standalone catalytic strippers $[36,40,41,44]$. For other standalone or with hot-dilution catalytic stripper systems, masses up to $8-15 \mathrm{mg} / \mathrm{m}^{3}$ had no particles remaining $[34,36,39]$. There was no difference between CS with or without sulfur trap, as both can remove hydrocarbon masses $>10 \mathrm{mg} / \mathrm{m}^{3}$ without any remaining particles.

\section{3. $\mathrm{H}_{2} \mathrm{SO}_{4}$}

Figure 3 summarizes the results for $\mathrm{H}_{2} \mathrm{SO}_{4}$ and $\mathrm{H}_{2} \mathrm{SO}_{4}$ with hydrocarbons (C24 or C28) for evaporation tube-based [32,35,38-41] and catalytic stripper-based [32,35,38-41,44] systems. Particles $>23 \mathrm{~nm}$ remained only with thermodenuder $\left(3.8 \mathrm{mg} / \mathrm{m}^{3}\right)$ [32] or evaporation tube after hot dilution $\left(0.3 \mathrm{mg} / \mathrm{m}^{3}\right)$ [39]. When the concentration was $1 \mathrm{mg} / \mathrm{m}^{3}$, some particles in the 10-23 nm range remained for the thermodenuder, and evaporation tube after hot dilution [40]. With mixture of $\mathrm{H}_{2} \mathrm{SO}_{4}$ with hydrocarbons, the evaporation tube had artefacts in the 10-23 nm range even at $0.1 \mathrm{mg} / \mathrm{m}^{3}$ [41]. Particles $<10 \mathrm{~nm}$ remained even at very low masses $\left(<0.2 \mathrm{mg} / \mathrm{m}^{3}\right.$ of $\mathrm{H}_{2} \mathrm{SO}_{4}$ or $\mathrm{H}_{2} \mathrm{SO}_{4}$ and $\mathrm{HCs}$ ) for the thermodenuder and the evaporation tube after hot dilution, although in one case, the evaporation tube with hot dilution could handle $2.5 \mathrm{mg} / \mathrm{m}^{3}$ with artefact $<10 \mathrm{~nm}$ [38]. Only the catalytic stripper could completely remove sulfuric acid aerosol without any particle remaining at concentrations ranging from $0.1 \mathrm{mg} / \mathrm{m}^{3}[35,39,41]$ to $1 \mathrm{mg} / \mathrm{m}^{3}$ [38] or even $9.3 \mathrm{mg} / \mathrm{m}^{3}$ [44]. At the $>10 \mathrm{mg} / \mathrm{m}^{3}$ range only one standalone catalytic stripper with a sulfur trap downstream of the oxidation catalyst was evaluated [44]. Although it could remove up to $9.3 \mathrm{mg} / \mathrm{m}^{3} \mathrm{H}_{2} \mathrm{SO}_{4}$ without any particles remaining, at $16 \mathrm{mg} / \mathrm{m}^{3}$ some particles remained below $10 \mathrm{~nm}$, and at $28 \mathrm{mg} / \mathrm{m}^{3}$ particles remained at the 10-23 nm range. Only one study compared a catalytic stripper with and without a sulfur trap [40]. The version with sulfur trap could handle up to $1 \mathrm{mg} / \mathrm{m}^{3}$ without significant artefacts while without the trap remaining particles were detected already on $\mathrm{H}_{2} \mathrm{SO}_{4}$ concentrations above $0.07 \mathrm{mg} / \mathrm{m}^{3}$. In general, catalytic strippers with a sulfur trap could handle higher $\mathrm{H}_{2} \mathrm{SO}_{4}$ containing aerosol. 


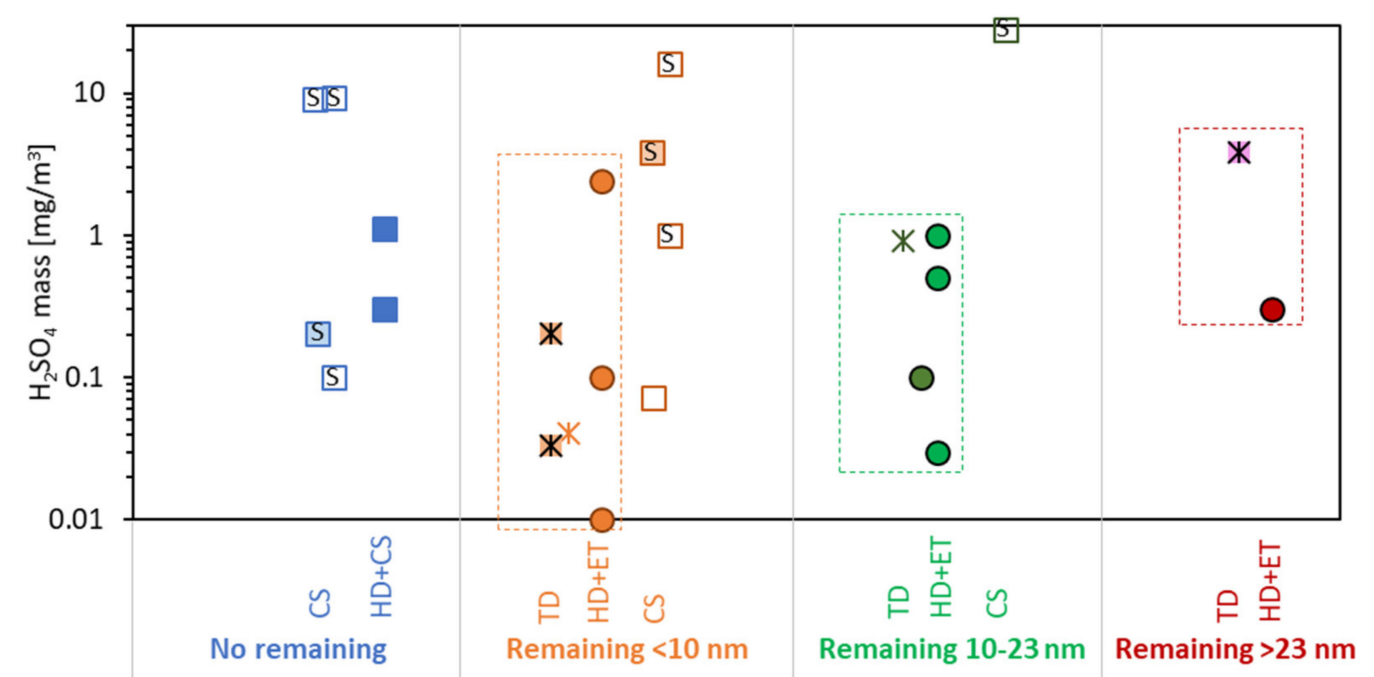

Figure 3. Volatile removal evaluation with sulfuric acid aerosol or sulfuric acid and hydrocarbons (symbols with background) depending on whether none or some particles remained (or re-nucleated) $<10 \mathrm{~nm}$, between 10 and $23 \mathrm{~nm}$, and $>23 \mathrm{~nm}$. Open circles: evaporation tubes (ET); asterisks: thermodenuders (TD); solid circles: hot dilution and evaporation tubes (HD + ET); open squares: catalytic strippers (CS); solid squares: hot dilution and catalytic strippers (HD + CS). "S" indicates CS with sulfur trap.

\subsection{Ammonium Sulfate}

A catalytic stripper based on a commercial vehicle aftertreatment DOC, used downstream of a hot dilution, could evaporate and shrink ammonium sulfate particles, but a residual with a mean between $10 \mathrm{~nm}$ and $20 \mathrm{~nm}$ remained due to the atomization method [29]. In another study, a CS downstream of a hot diluter started to show some breakthrough only at inlet concentration of around $1 \times 10^{7} \mathrm{p} / \mathrm{cm}^{3}\left(8.5 \mathrm{mg} / \mathrm{m}^{3}\right)$ [39]. The hot diluter and evaporation tube combination had breakthrough at a one order of magnitude lower concentrations. A later study confirmed the findings and showed that the breakthrough particles had a size $<23 \mathrm{~nm}$ [38].

\subsection{Vehicles' Exhaust}

Figure 4, which is organized in the same way as the previous figures, summarizes the results with vehicles' exhaust for evaporation tube $[3,8,33,34,41,49-57]$ and catalytic stripper $[3,8,33,34,41,50,52,57]$ systems. The volatile mass concentrations refer to the inlet of the systems, which were sampling from the full dilution tunnel. They were estimated from the nucleation mode size distributions. The horizontal lines indicate the levels of volatiles of the different tested categories: mopeds $>10 \mathrm{mg} / \mathrm{m}^{3}$, diesel with DPF but without diesel oxidation catalyst (DOC) $6 \mathrm{mg} / \mathrm{m}^{3}$, and all the rest (GDI, DPF regenerations and heavy duty diesel vehicles) $<1 \mathrm{mg} / \mathrm{m}^{3}$. The chemical composition of the volatiles is unknown (i.e., was not measured in any of the studies).

The hot dilution and evaporation tube had cases with remaining particles even at low levels: with $0.05 \mathrm{mg} / \mathrm{m}^{3}$ there were particles $<10 \mathrm{~nm}$ [41], while with mass $0.5 \mathrm{mg} / \mathrm{m}^{3}$ or higher particles 10-23 nm remained (in one case also particles $>23 \mathrm{~nm}$ ) [49]. However, there was a case in which the hot dilution and evaporation tube could handle $15 \mathrm{mg} / \mathrm{m}^{3}$ without artefacts (primary hot dilution 25:1) [34]. The catalytic stripper (standalone or downstream of a hot dilution) did not have cases where particles $>10 \mathrm{~nm}$ remained. There were cases that particles $<10 \mathrm{~nm}$ remained at mass concentrations $0.65 \mathrm{mg} / \mathrm{m}^{3}$ [52] or $6.1 \mathrm{mg} / \mathrm{m}^{3}$ [33] (as standalone) or $30-50 \mathrm{mg} / \mathrm{m}^{3}$ downstream of a hot dilution [8,34]. There were many experiments with CS that no particles remained with concentrations even $>10 \mathrm{mg} / \mathrm{m}^{3}$. 


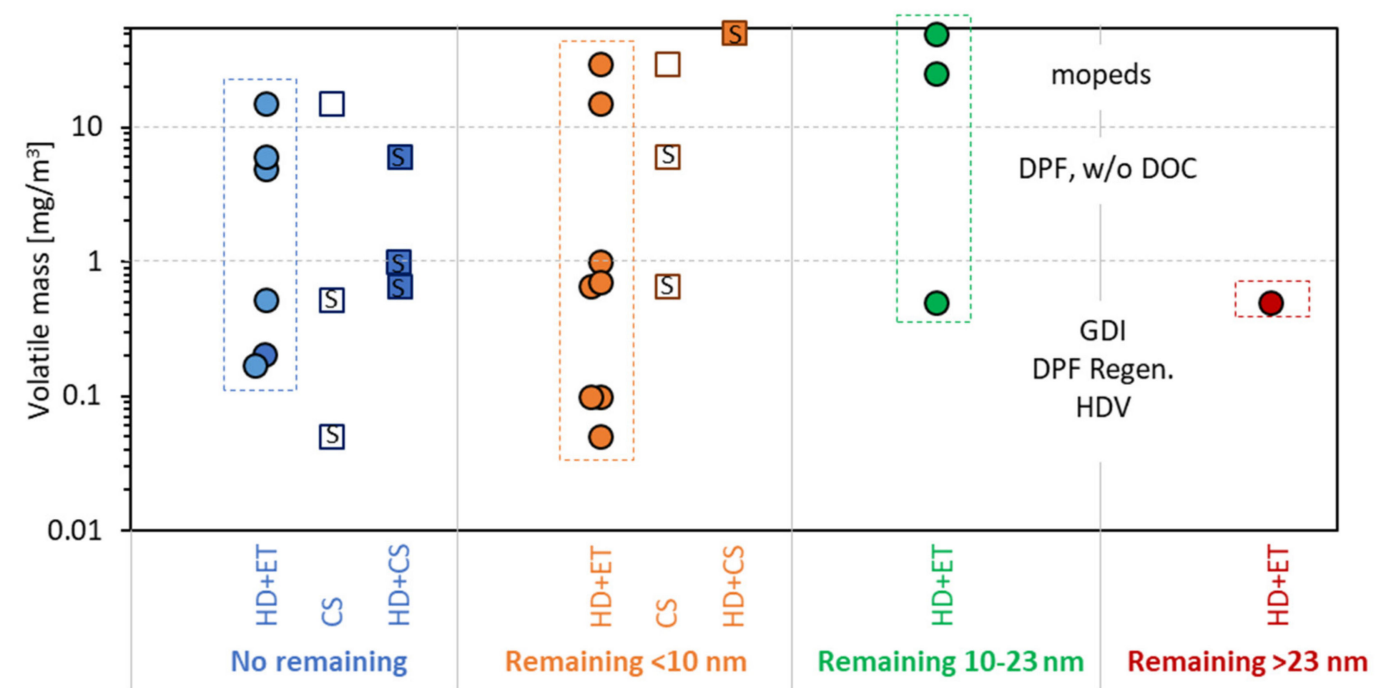

Figure 4. Volatile removal evaluation with vehicles' exhaust depending on whether none or some particles remained (or re-nucleated) $<10 \mathrm{~nm}$, between 10 and $23 \mathrm{~nm}$, and $>23 \mathrm{~nm}$. Solid circles: hot dilution and evaporation tubes (HD + ET); open squares: catalytic strippers (CS); solid squares: hot dilution and catalytic strippers (HD + CS). "S" indicates CS with sulfur trap. DOC = diesel oxidation catalyst; $\mathrm{DPF}=$ diesel particulate filter; GDI = gasoline direct injection; HDV = heavy-duty vehicle.

\section{Discussion}

This review summarized the studies that evaluated evaporation tubes and catalytic strippers with laboratory or vehicles' exhaust aerosol. The implications of the results will be discussed in the following sections.

\subsection{Evaporation Tube}

The concept that was introduced in the particle number regulations is very efficient, as summarized in the literature [14]. The hot dilution with the evaporation tube in combination with a counter that measures particles $>23 \mathrm{~nm}$ is a reliable methodology as artefacts have rarely been reported.

The temperature of the evaporation tube and the residence time is appropriate for the evaporation of volatile particles. The theory estimates necessary time around 10-16 ms for typical commercial systems [5,44], which is much less than the 200-400 ms residence time in the systems, although the available time at the critical temperature region $\left(>250{ }^{\circ} \mathrm{C}\right)$ is shorter. The upstream dilution at $150{ }^{\circ} \mathrm{C}$ pre-heats the sample and ensures that the desired temperature will be reached in the evaporation tube. Most importantly, it dilutes the sample and reduces the partial pressures, thus minimizing the possibility of nucleation downstream of the evaporation tube. Nevertheless, nucleation has been reported many times with both laboratory and vehicles' exhaust aerosol. Theoretically, the nucleation of hydrocarbons is unlikely because very high concentrations are required $\left(>3 \mathrm{mg} / \mathrm{m}^{3}\right.$ [5]). However, the experimental data with laboratory hydrocarbon aerosols showed that standalone evaporation tubes could not handle $0.25 \mathrm{mg} / \mathrm{m}^{3}$. Evaporation tubes, even with a hot dilution upstream (dilution 10:1), could not handle $8.5 \mathrm{mg} / \mathrm{m}^{3}\left(0.85 \mathrm{mg} / \mathrm{m}^{3}\right.$ at the inlet of the evaporation tube $)$ as particles $<10 \mathrm{~nm}$ remained (or nucleated). The case where particles $>23 \mathrm{~nm}$ remained was atomized emery oil $\left(15 \mathrm{mg} / \mathrm{m}^{3}\right)$ with hot dilution 25:1. In this case it is possible that there were impurities and the evaporated emery oil condensed on the solid residuals downstream of the evaporation tube growing them to the over 23 nm range [48].

When sulfuric acid is available, formation of nucleation particles is very probable. Theoretical calculation and experimental results have shown nucleation possibility even at $0.3 \mu \mathrm{g} / \mathrm{m}^{3}$ levels [5]. Small amounts of ammonia ( $<20 \mathrm{ppb})$ may significantly enhance the binary nucleation rate of sulfuric acid and water [58-60], for example at vehicles with SCR (selective catalytic reduction for $\mathrm{NO}_{\mathrm{x}}$ ) 
systems or gasoline vehicles with three-way catalysts (TWC) [61]. Experimentally, nucleation particles downstream of a VPR with evaporation tube were measured from a heavy-duty vehicle equipped with SCR [62]. However, the size of the $\mathrm{H}_{2} \mathrm{SO}_{4}$ nuclei (critical clusters) is approximately 1-1.5 nm and high concentrations of $\mathrm{H}_{2} \mathrm{SO}_{4}$ are needed to grow them to $3 \mathrm{~nm}$ in diameter [63,64]. Interestingly, laboratory experiments with sulfuric acid (and humidity) have reported size distributions peaking at $18 \mathrm{~nm}$ [65] or even $>200 \mathrm{~nm}$ [44]. Similarly, experiments with $\mathrm{SO}_{2}$ (converted to $\mathrm{SO}_{3}$ ) gave nucleation modes peaking at $16 \mathrm{~nm}\left(1.8 \mathrm{ppm} \mathrm{SO}_{2}\right)$ [66], $45 \mathrm{~nm}\left(61.4 \mathrm{ppm} \mathrm{SO}_{2}\right)$ [66], or even $>70 \mathrm{~nm}(200 \mathrm{ppm})$ [33].

Nuclei typically grow to bigger than $3 \mathrm{~nm}$ sizes with organics [67], even at low concentrations as experiments with heavy-duty engine have shown [68]. The fuel sulfur was $1 \mathrm{ppm}$, and the (effective) contribution of the lubricant was 2-9 ppm (estimated sulfuric acid concentration 1.5-5.8 $\times 10^{12} \mathrm{~cm}^{-3}$ ) and the final mean size was $<10 \mathrm{~nm}$ [69]. The nucleation mode peaked at $15 \mathrm{~nm}$ when the sulfur (fuel plus effective lubricant) was approximately $50 \mathrm{ppm}$ (sulfuric acid $3.3 \times 10^{13} \mathrm{~cm}^{-3}$ ). Growth rates of $6-24 \mathrm{~nm} / \mathrm{s}$ were measured for a heavy-duty engine with $8 \mathrm{mg} / \mathrm{m}^{3}$ organics emissions [70]. Another study found a nucleation mode of $6 \mathrm{~nm}$ when organics were available with concentration $10^{11} \mathrm{~cm}^{-3}$ [71]. With appropriate residence time $(1 \mathrm{~s})$, in the presence of a high amount of organics $\left(10^{14} \mathrm{~cm}^{-3}\right)$ the nucleation mode peaked at $20 \mathrm{~nm}$ [72]. Approximately $1 \mathrm{ppm}$ of propane corresponds to $1 \times 10^{12} \mathrm{~cm}^{-3}$ organics [73]. This is calculated using the appropriate molecular mass and an assumed $10-30 \%$ fraction of total organics potentially condensing on the particulates phase [73]. Thus, it can be assumed that with hydrocarbon concentrations $>100 \mathrm{ppm}$ at the outlet of the evaporation tube the nucleated sulfuric acid particles can grow to sizes of $20 \mathrm{~nm}$.

The laboratory tests with sulfuric acid (and hydrocarbons in some cases) confirmed the previous studies. In all cases with the evaporation tubes there was re-nucleation. Mass of $0.9 \mathrm{mg} / \mathrm{m}^{3}$ or lower resulted in nucleation mode particles $>10 \mathrm{~nm}$ even with a hot dilution of 10:1. However, for the majority of the cases, with high dilution ratios ( $>100: 1$ primary hot dilution) there are no reported cases of re-nucleation [74] except with 2-stroke mopeds. Studies comparing evaporation tubes with catalytic strippers gave equivalent results (within 10\%) for both $23 \mathrm{~nm}$ and $10 \mathrm{~nm}$ systems [39,75,76]. Higher differences of the $10 \mathrm{~nm}$ systems were attributed to the different cut-off curves of the counters.

\subsection{Catalytic Stripper}

The studies with catalytic strippers proved that much higher concentrations can be handled for both hydrocarbons and/or sulfuric acid aerosols than with evaporation tubes. For example, no artefacts were seen when catalytic strippers were challenged with hydrocarbons. In a few cases without hot pre-diluter particles $<10 \mathrm{~nm}$ remained. Similarly, most concentrations of sulfuric acid were efficiently removed. Only in a few cases standalone systems had particles remaining $<10 \mathrm{~nm}$. The results with vehicle exhaust were similar to the laboratory aerosols. The standalone catalytic stripper had in some cases particles remaining $<10 \mathrm{~nm}$, while the evaporation tube systems often had particles remaining $>10 \mathrm{~nm}$ at various challenge mass levels.

The conclusion based on the current experimental results is to use a catalytic stripper when measurements of particles $>10 \mathrm{~nm}$ are conducted. For lower sizes, the catalytic stripper is necessary, but not artefact-free, and a hot pre-diluter is recommended. For lower than $10 \mathrm{~nm}$ measurements, the high particle losses of the catalytic stripper have also to be considered.

\subsubsection{Oxidation and Sulfur Trap Parts}

Figure 5a plots separately examples of the two parts of a catalytic stripper: the oxidation part and the sulfur storage part. In actual catalytic strippers the two parts are continuous. At some catalytic strippers the sulfur trap is upstream of the oxidation part, in some downstream, and in some others it does not exist. As discussed before (Figure 1), the oxidation part evaporates nucleation mode particles and oxidizes the volatile particles (actually the particles should be evaporated earlier in an evaporation tube in order to have more efficient oxidation in the gaseous phase). The condensed material on the soot particles is also evaporated and oxidized. In this oxidation part the $\mathrm{SO}_{2}$ and $\mathrm{SO}_{3}$ 
are considered to remain unaffected; especially catalytic strippers without a sulfur trap rely on this assumption. The actual $\mathrm{SO}_{2}$ to $\mathrm{SO}_{3}$ conversion, however, depends on the catalyst formulation as will be discussed in Section 4.2.2. Modern engines equipped with oxidation converters and depending on the fuel and lubricant sulfur content, can have relatively high $\mathrm{SO}_{3}$ concentrations and this could result in nucleation of sulfuric acid at the exit of the catalytic stripper. The sulfur trap retains sulfur, minimizing this possibility.

At low temperatures $\left(<350^{\circ} \mathrm{C}\right)$ sulfur is stored through adsorption or condensation (physically bounded sulfate), while, at higher temperatures $\left(>400^{\circ} \mathrm{C}\right)$ sulfur is stored as chemically bound metal sulfate [77]. Adhesion of sulfate in mist form on the catalyst is also possible at low temperatures. Under oxygen deficient conditions $\mathrm{H}_{2} \mathrm{~S}$ is formed, which is poisonous for metal surfaces.

Sulfur traps may include an oxidation catalyst, e.g., platinum, to facilitate the $\mathrm{SO}_{2}$ to $\mathrm{SO}_{3}$ reaction. Typical sulfur storage systems are based on alkaline earth or alkali metal oxides and their mixtures on alumina washcoat. Other materials such as zinc, nickel, chromium, and copper are used either as stand-alone scavengers or as promoters, to modify trap performance, strengthen desired reactions, and influence the adsorption/desorption temperatures.

\subsection{2. $\mathrm{SO}_{2}$ to $\mathrm{SO}_{3}$ Conversion}

Figure 5 b summarizes $\mathrm{SO}_{2}$ to $\mathrm{SO}_{3}$ conversion efficiencies from the literature of commonly used oxidation catalysts (based also on the review in [78]). The space velocity was around 35,000-50,000 $\mathrm{h}^{-1}$. Higher space velocities result in lower conversions $[79,80]$. Conversion rates for other catalyst materials can be found in the literature (e.g., [81,82]). The extent of the conversion depends mainly on the exhaust gas temperature, the type of noble metal used and the loading, and composition of the washcoat. The $\mathrm{SO}_{2}$ to $\mathrm{SO}_{3}$ conversion starts to increase at around $200{ }^{\circ} \mathrm{C}$, reaches a maximum at $450{ }^{\circ} \mathrm{C}$ as the reaction kinetics accelerate and then gradually decreases due to thermodynamic equilibrium limitations. The three studies with catalytic strippers are in agreement with the published data and vary from $0 \%$ to $37.5 \%$ at $275{ }^{\circ} \mathrm{C}$ to $300{ }^{\circ} \mathrm{C}$ actual aerosol temperature $[30,33,36]$. The need for a low or high $\mathrm{SO}_{2}$ to $\mathrm{SO}_{3}$ conversion depends on the concept of the catalytic stripper (only oxidation part or with sulfur trap).

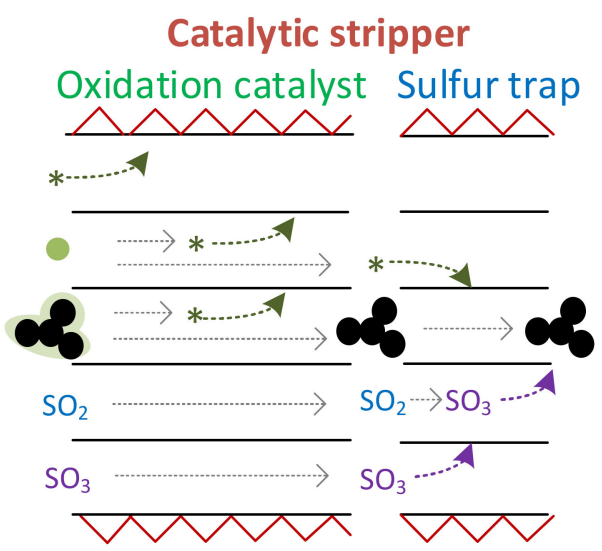

(a)

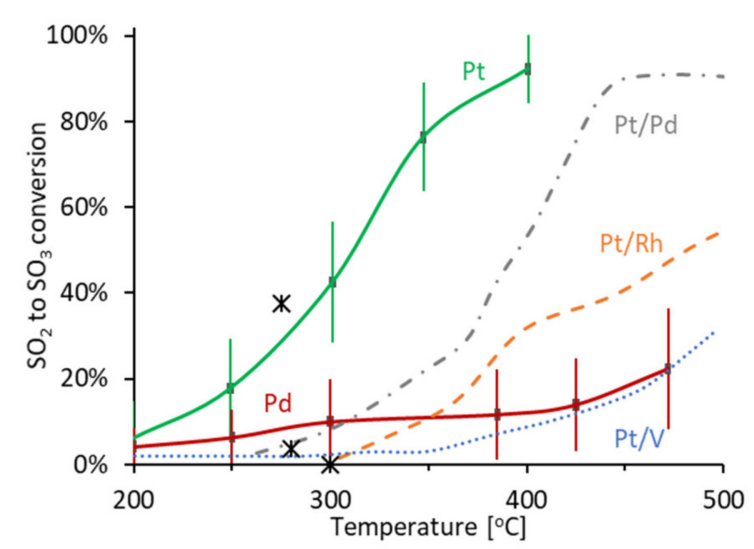

(b)

Figure 5. Catalytic stripper: (a) the two parts of a catalytic stripper: oxidation catalyst and sulfur trap. Products of reactions such as $\mathrm{CO}_{2}$ and $\mathrm{H}_{2} \mathrm{O}$ are not plotted; (b) $\mathrm{SO}_{2}$ to $\mathrm{SO}_{3}$ conversion for various noble metals and combinations. Pt [79,83-86], Pt/Pd [87], Pt/Rh [87], Pt/V [84], Pd [84,87]. Asterisks are experimental data with catalytic strippers $[30,33,36]$.

\subsubsection{Storage Capacity}

The $\mathrm{SO}_{\mathrm{x}}\left(\mathrm{SO}_{2}\right.$ and/or $\left.\mathrm{SO}_{3}\right)$ retention capacity is typically expressed in milligrams of $\mathrm{SO}_{\mathrm{x}}$ captured per gram of sorbent. A review of the literature of sorbent systems for the removal of the $\mathrm{SO}_{\mathrm{x}}$ from 
flue gases reported values from a few $\mathrm{mg}$ to hundreds of $\mathrm{mg}$ per gram of sorbent [88]. In vehicle applications, the catalyst capacity in sulfate storage depends on the noble metal and the washcoat composition. Studies with diesel oxidation catalysts (DOCs) with $1 \% \mathrm{Pt}$ on alumina found 16-50 mg sulfates per gram of washcoat $(1.6-5 \%)$ at $350{ }^{\circ} \mathrm{C}[80,89,90]$, but $0 \%$ for $\mathrm{SiC}$ washcoat [89]. A Pd on alumina adsorbed up to $7 \% \mathrm{SO}_{2}$ at $320^{\circ} \mathrm{C}$ [91]. At temperatures higher than $400{ }^{\circ} \mathrm{C}$, percentages of up to $4 \%$ have been reported for $\mathrm{Pt}, \mathrm{Pt} / \mathrm{Pd}$, or $\mathrm{Pt} / \mathrm{V}$ catalysts [84,92-94]. Dedicated studies with sulfur traps have reported $\mathrm{SO}_{2}$ capacity of $40-70 \%$ at temperatures $300-400{ }^{\circ} \mathrm{C}[95,96]$.

Materials are generally post-characterized for total sulfur content. However, a substantial concentration of $\mathrm{SO}_{3}$ can be present in the flue gas well before the total capacity is reached [81]. This means that the total capacity of an absorber or adsorber is a poor indication of actual performance during operation. Therefore, the performance of catalytic strippers is characterized in real time.

Figure 6 plots a hypothetical sulfur storage test based on published similar studies [20,33,36,83,97-103]. At time $\mathrm{t}_{0}, \mathrm{SO}_{2}$ in $\mathrm{O}_{2}$ and $\mathrm{N}_{2}$ is inserted in the catalytic stripper. The $\mathrm{SO}_{2}$ level is typically between 20 and $150 \mathrm{ppm}$ (100\% in the figure) in order to have adequate measurement accuracy with the $\mathrm{SO}_{2}$ analyzer. Initially, the measured $\mathrm{SO}_{2}$ outlet concentration is zero because the $\mathrm{SO}_{2}$ is stored in the trap (either as $\mathrm{SO}_{2}$ or metal sulfate after conversion to $\mathrm{SO}_{3}$ ). At some point $\left(\mathrm{t}_{\mathrm{b}}\right)$ breakthrough of $\mathrm{SO}_{2}$ will start. From this point, the trapping efficiency is not $100 \% . \mathrm{SO}_{3}$ will also start to appear at the outlet of the catalytic stripper. For simplification, in this figure, it is assumed that $\mathrm{SO}_{3}$ appears at the same time with the $\mathrm{SO}_{2}$, but this is not necessarily true. $\mathrm{This} \mathrm{SO}_{3}$ poses a risk for particles formation. Figure $6 \mathrm{~b}$ gives an example of a particle size distribution measured at the outlet of the catalytic stripper during the breakthrough period $\left(\mathrm{t}_{2}\right)$. Note that during the initial storage phase no particles were emitted $\left(\mathrm{t}_{1}\right)$. At point $\left(\mathrm{t}_{\mathrm{eq}}\right)$ the sulfur storage capacity will be saturated and the $\mathrm{SO}_{2}$ and $\mathrm{SO}_{3}$ outlet concentrations will be stabilized. From $t_{\text {eq }}$ the sulfur trap is behaving like an oxidation catalyst and produces $\mathrm{SO}_{3}$ with high probability for particle formation (Figure $6 \mathrm{~b}$, size distribution $\mathrm{t}_{3}$ ). The exact time of appearance and the magnitude of the size distributions depend on many parameters such as $\mathrm{SO}_{2}$ levels, $\mathrm{SO}_{2}$ to $\mathrm{SO}_{3}$ conversion rate, humidity, and availability of hydrocarbons $[33,66]$. The transition from $t_{b}$ to $t_{\text {eq }}$ was plotted as a linear function for simplicity reasons; however, in reality it is sigmoidal-like curve.

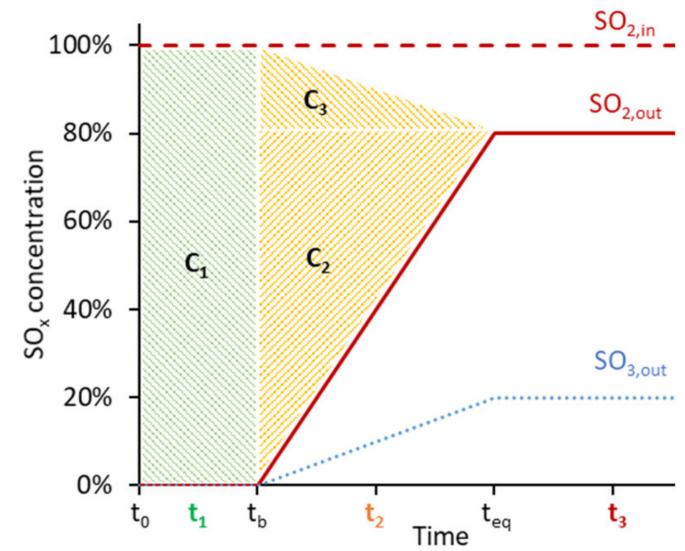

(a)

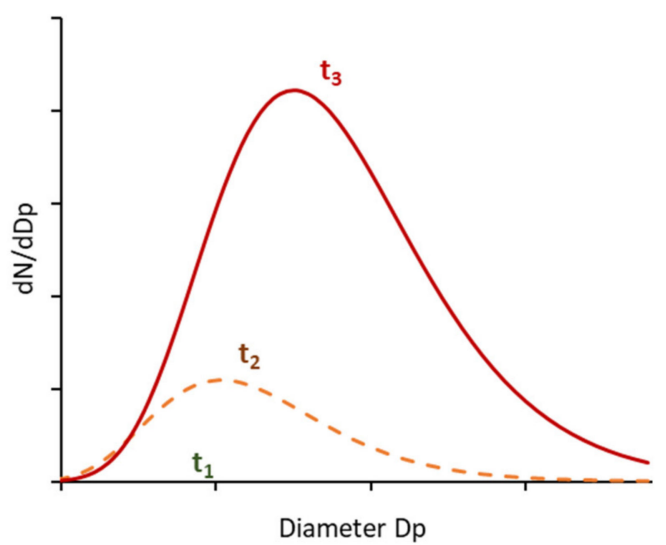

(b)

Figure 6. Hypothetical sulfur storage test with $\mathrm{SO}_{2}$ : (a) $\mathrm{SO}_{\mathrm{x}}$ concentrations over time; (b) particle size distributions during the sulfur storage test.

The "total storage capacity" area is $\mathrm{C}_{1}+\mathrm{C}_{2}+\mathrm{C}_{3}$. Note that usually there are no $\mathrm{SO}_{3}$ measurements, so the determination of $\mathrm{C}_{3}$ is not possible and not reported. Note also that even if the $\mathrm{SO}_{3}$ breakthrough starts after the $\mathrm{SO}_{2}$ breakthrough, the definitions of the areas remain the same, because if there is already $\mathrm{SO}_{3}$ in the aerosol, it might not be completely stored in the sulfur trap already at time $\mathrm{t}_{\mathrm{b}}$. The important area, however, is $C_{1}$, which is called "complete storage capacity". The determination of 
the breakthrough point $\left(\mathrm{t}_{\mathrm{b}}\right)$ is typically set to $1 \% \mathrm{SO}_{2}$ to cover the uncertainty of the $\mathrm{SO}_{2}$ measurement, but $0 \%$ has also been used for catalytic strippers.

The sulfur mass $C_{m}[\mathrm{mg} / \mathrm{s}]$ passing through the catalyst is:

$$
C_{m}=10^{-6} \times C_{v} \times \rho_{S O 2} \times(Q / 60) \times\left(M_{S} / M_{S O 2}\right) \times 10^{3},
$$

where $C_{v}$ is the $\mathrm{SO}_{2}$ passing through the catalyst [ppmv], $\rho_{S O 2}$ is the density of $\mathrm{SO}_{2}$ at $0{ }^{\circ} \mathrm{C}[2.86 \mathrm{~g} / \mathrm{L}]$, $Q$ is the catalytic stripper flow rate at $0{ }^{\circ} \mathrm{C}[\mathrm{L} / \mathrm{min}], M_{S}$ is the molecular mass of sulfur [ $\left.32 \mathrm{~g} / \mathrm{mol}\right], M_{S O 2}$ is the molecular weight of sulfur dioxide $[64 \mathrm{~g} / \mathrm{mol}]$. The sulfur capacity $C$ [mg S] can be estimated by integrating $C_{m}$ for the appropriate time and assuming a retention efficiency $R$. Typically, the "complete" capacity should be reported $\left(C_{1}\right.$ in Figure $\left.6 a\right)$, where the retention efficiency $R$ is $100 \%$ (integration until $t_{b}$ ). After $t_{b}$ the retention efficiency can be estimated from the surface area of the graph.

$$
C=\Sigma_{0-\mathrm{t}}\left(R_{i} \times C_{m}\right)
$$

The composition and the amount of the washcoat of catalytic strippers is not disclosed, so "total" captured sulfur mass is reported (or mass/L of catalyst). Values of approximately 6-23 mg or 0.7-1 g/L have been reported [33,36], with re-nucleation artefacts beginning already at $20-40 \%$ of the capacity. It can be assumed that research in this area can further increase the storage capacity. For example, a sulfur trap stored almost up to $15 \mathrm{~g} / \mathrm{L}$ with no evidence of poisoning of a $\mathrm{NO}_{\mathrm{x}}$ catalyst downstream of the sulfur trap [104].

Based on Equations (1) and (2), the time until saturation $t$ [h] of a catalytic stripper with sulfur trap can be estimated based on the following equation:

$$
t=11.7 \times C / Q / E
$$

where $E$ are the expected $\mathrm{SO}_{\mathrm{x}}$ emissions [ppmv $\mathrm{SO}_{\mathrm{x}}$ ]. Assuming $2.5 \mathrm{mg}$ effective (complete) sulfur capacity $\left(\mathrm{C}_{1}\right.$ in Figure $\left.6 \mathrm{a}\right)$ and $1 \mathrm{~L} / \mathrm{min}$ flowrate, for $0.5 \mathrm{ppm} \mathrm{SO}$ emissions, the time until saturation would be $58 \mathrm{~h}$. Considering the dilution at the dilution tunnel and at the pre-diluter, this time would increase approximately 100 times. Similarly, a system at the tailpipe would also use a high dilution of at least 100:1. It should be highlighted that a catalytic stripper used directly at the tailpipe needs some dilution in order to ensure that enough oxygen will be available for oxidation at rich or stoichiometric modes of engine operation.

\subsubsection{Position of Sulfur Trap}

The first CS with sulfur trap had the trap upstream of the oxidation catalyst in order to protect the oxidation catalyst from poisoning [31,105], because the sulfates formed inhibit reactants from adsorbing on the active sites [77,106]. Tests showed that the total sulfur capacity was $60 \%$ lower compared to the configuration where the sulfur trap was downstream [33]. It was assumed that, the sulfur was primarily stored as $\mathrm{SO}_{2}$, because no $\mathrm{SO}_{3}$ was available upstream of the sulfur trap. Further tests showed that poisoning of the oxidation catalyst (saturated with sulfur) did not affect the volatile removal [36]. Nevertheless, the light-off temperatures were lower when the sulfur trap was upstream [33]. As the catalytic stripper is used at a constant high temperature $\left(350{ }^{\circ} \mathrm{C}\right)$, the light-off temperature is not of concern. For these reasons, the downstream position is the preferred one in commercial systems.

\subsection{Open Issues}

The superiority of the catalytic stripper compared to the evaporation tube for sub-23 $\mathrm{nm}$ measurements was shown experimentally in many studies. The addition of a sulfur trap in many cases gave an advantage of retention of sulfuric acid. However, there are no technical requirements or specifications for catalytic strippers, so non-optimized systems might be used resulting in lower 
than expected performance. The following sections will discuss issues related to particle losses, sulfur storage capacity, and typical vehicles' aerosol.

\subsubsection{Particle Losses}

The particle losses in a volatile particle remover are due to diffusion and thermophoresis. The thermophoretic losses are around $25 \%$ without any dilution downstream of the volatile particle remover, but less than $10 \%$ with dilution. The diffusion losses are size-dependent and for catalytic strippers are from $15 \%$ to $40 \%$ more compared to $100 \mathrm{~nm}[29,33,36]$. The thermophoretic losses are similar for catalytic strippers and evaporation tubes for similar setup. The major drawback of catalytic strippers versus evaporation tubes is the additional size dependent diffusion losses. Tests with a particle number system replacing the evaporation tube with a catalytic stripper gave $<20 \%$ difference at the $10 \mathrm{~nm}$ losses [39]. The design of a catalytic stripper is a compromise between volatile removal efficiency and non-volatile particles' penetrations [29,44]. Particle number systems with optimized catalytic strippers have achieved $<20 \%$ losses at $10 \mathrm{~nm}[29,36]$, but typically the losses are higher [39,107]. The regulation uses an average particle number concentration reduction factor (PCRF) of $30 \mathrm{~nm}, 50 \mathrm{~nm}$, and $100 \mathrm{~nm}$ to take into account the particle losses and the dilution ratio. This average PCRF is based on the fact that vehicles' size distributions have geometric mean diameter around $50 \mathrm{~nm}$. In order to minimize the influence of the small particle losses on the results, restrictions for the sub- $23 \mathrm{~nm}$ sizes are necessary. The future $>10 \mathrm{~nm}$ regulation will have a limit for the ratio $\mathrm{PCRF}_{15}$ to $\mathrm{PCRF}_{100}$ of $<2$. Another solution is to use two particle number counters with different cut-off sizes (at 23 and $10 \mathrm{~nm}$, approximately) and correct for the losses below $23 \mathrm{~nm}$ [8].

For $30 \mathrm{~nm}$ (and larger) sizes the differences of the losses between identical systems with evaporation tubes or catalytic strippers are less than $10 \%$ [39]. This value is well within the range seen between various commercial systems with evaporation tubes. The average PCRF, which takes into account the losses at $30 \mathrm{~nm}, 50 \mathrm{~nm}$ and $100 \mathrm{~nm}$, will partly offset the size-dependent losses. Furthermore, the penetration of the complete system does not depend so much on the VPR, but mainly on the PNC [76]. Consequently, the differences of the systems with $23 \mathrm{~nm}$ PNCs will be within the typical experimental uncertainties (5\%). Indeed, most comparisons of $>23 \mathrm{~nm}$ systems with and without catalytic strippers gave comparable results $[39,75,76]$. With the current regulations, catalytic strippers are not allowed in the volatile particle removers, because it is required that the materials do not react with exhaust gas components. However, assuming that a system with catalytic stripper fulfils all the rest requirements (e.g., $\mathrm{PCRF}_{30}$ to $\mathrm{PCRF}_{100}$ ratio $<1.3$ ), and based on the aforementioned findings, there is no reason to exclude catalytic strippers for $>23 \mathrm{~nm}$ measurements. Thus, future regulation should permit the use of catalytic strippers even for measurements of particles $>23 \mathrm{~nm}$.

\subsection{2. $\mathrm{SO}_{3}$ Conversion Risks}

The catalytic strippers with only the oxidation part do not convert $\mathrm{SO}_{2}$ to $\mathrm{SO}_{3}$, but this needs to be checked, because at the temperature required by the regulation $\left(350{ }^{\circ} \mathrm{C}\right)$ some conversion may take place (as discussed in Figure $5 b$ ). This could result in higher risk for re-nucleation compared to an evaporation tube (where no $\mathrm{SO}_{2}$ to $\mathrm{SO}_{3}$ conversion takes place). In this case it is necessary that most of the hydrocarbons are removed, so the nuclei will not grow to the measurement range of the counting instruments.

Catalytic strippers with sulfur trap showed efficient removal even for high concentrations of sulfuric acid. However, the risk with these systems is that they may be saturated if proper attention is not given. At the moment there is no alarm/warning for such cases. Due to their high $\mathrm{SO}_{2}$ to $\mathrm{SO}_{3}$ conversion, when they are saturated they may result in higher nucleation probability compared to the simple oxidation catalytic strippers or evaporation tubes. For modern light-duty vehicles with low sulfur fuel and lubricant, the time until saturation is hundreds of hours (with some dilution) [33]. For applications using high sulfur content fuels (e.g., marine engines), however, they could saturate only in a couple of hours [35]. Maximum $\mathrm{SO}_{2}$ concentrations are given in Table 2 for recent technologies (and 
fuels). Higher concentrations could be measured when the fuel sulfur content is $>15 \mathrm{ppm}$, e.g., in India, Central and South America or in Africa [108]. For example, the expected $\mathrm{SO}_{2}$ concentrations are $<1 \mathrm{ppm}$ for modern vehicles [35], and peaks of 20 ppm may appear, and in extreme cases (e.g., regenerations) even higher (150 ppm) [109]. However, measurement campaigns in countries with high sulfur content fuel have reported average $\mathrm{SO}_{2}$ concentrations of 20-120 ppm [110] or even higher when there were maintenance issues with the vehicles [111]. As it was discussed in Figure 6b, high $\mathrm{SO}_{2}$ or $\mathrm{SO}_{3}$ concentrations can result in sulfuric acid nucleation particles peaking at sizes $>10 \mathrm{~nm}[33,66]$.

In addition to the $\mathrm{SO}_{2}$ to $\mathrm{SO}_{3}$ reaction, it is not well understood how the catalytic strippers react with the exhaust aerosol. In a few cases non-volatile particle formation has been found in evaporation tubes, but also in catalytic strippers [32,41]. In another case, a catalytic stripper measured higher non-volatile particle concentrations than an evaporation tube [50]. This is an area that needs further research.

\subsubsection{Vehicles' Volatile Aerosol}

Table 2 gives the mass of volatiles reported as nucleation mode (NM) particles in the literature. These are the actual (maximum) levels that particle number systems may be challenged with. What is not always known is the chemical composition, and when detailed analysis is undertaken, hundreds of compounds can be found [112]. Furthermore, it is not possible to define easily a "typical" composition as it depends on the engine out emissions, the aftertreatment devices, the fuel, the lubricant, and the driving style. For example, for a heavy-duty engine without aftertreatment devices, branched alkanes and alkyl-substituted cycloalkanes from unburned fuel and/or lubricating oil contributed $>95 \%$ of the nanoparticle mass, and sulfuric acid $<5 \%$ [113]. Another study indicated that the organic component of diesel nanoparticles comprised compounds with carbon numbers in the C24-C32 range, derived almost entirely from unburned oil [114]. For a heavy-duty diesel vehicle with a catalyzed continuously regenerating trap (CRT) and $420 \mathrm{ppm}$ sulfur fuel the majority of the NM was sulfates [115]. Similarly, for light-duty NM particles, the sulfate to organic ratios were from 0.2 to 20 depending on the engine load (and exhaust gas temperature) for $350 \mathrm{ppm}$ fuel sulfur [116]. Chemical analysis of a heavy-duty DPF having mainly nucleation mode particles $\left(1.2 \times 10^{11} \mathrm{p} / \mathrm{km}\right)$ showed a high amount of BTEX compounds (benzene, toluene, ethylbenzene, m,p-xylenes, and o-xylene) and PAHs (polycyclic aromatic hydrocarbons) [117]. Similar results were noted for light-duty vehicles and, additionally, alkanes had high concentrations [118]. Toluene, isopentane, m,p-xylene, 1,2,4-trimethylbenzene, and o-xylene were the dominant volatile organic compounds emitted from the tailpipe exhaust of the motorcycles [119].

Table 2. Peak concentrations during cold start, during the test cycle or regenerations. $\mathrm{HCs}$ and $\mathrm{SO}_{2}$ concentrations refer to the tailpipe, NM to the dilution tunnel. $\mathrm{HC}=$ hydrocarbons; $\mathrm{HD}=$ heavy-duty; $\mathrm{LD}=$ light-duty; $\mathrm{NM}=$ nucleation mode.

\begin{tabular}{cccccc}
\hline Technology & Period & $\mathbf{N M}\left[\mathbf{m g} / \mathbf{m}^{3}\right]$ & Gas HCs $[\mathbf{p p m}]$ & $\mathbf{S O}_{2}$ [ppm] & References \\
\hline Moped & Cold start & $>10$ & $>50,000$ & 60 & {$[8,34,49]$} \\
Motorcycle & Cold start & & $10,000-35,000$ & $12-20$ & {$[120-122]$} \\
Motorcycle & Cycle & 0.4 & $300-5000$ & $9-20$ & {$[123,124]$} \\
LD Gasoline & Cold start & 5 & 12,000 & 10 & {$[125-130]$} \\
LD Diesel & Cold start & low & 350 & 10 & {$[128,131]$} \\
LD Diesel & Regeneration & 1 & 200 & 25 & {$[57,132-134]$} \\
HD Diesel & Regeneration & $1-12$ & 250 & 150 & {$[109,115,135-139]$} \\
\hline
\end{tabular}

For completeness, examples of measured gaseous hydrocarbons are given in Table 1 . They are measured according to the regulated procedure (with heated line at $191{ }^{\circ} \mathrm{C}$ ), thus they represent "light" hydrocarbons and they do not necessarily correlate with the NM reported in the same table. Furthermore, typically less than $30 \%$ of total HC is condensed on soot particles. The catalytic strippers remove the hydrocarbons more efficiently in the gas phase than in the particle phase [33]. Thus, the 
interpretation of these concentrations as requirements for catalytic strippers should be done with precaution. Moreover, the gas oxidation efficiency check may not be necessary if the volatile particles' removal efficiency is checked. Nevertheless, it could be a useful and easy check for the long term volatile removal efficiency stability, especially as the catalytic stripper is poisoned by sulfur compounds over time. At the temperatures prescribed in the regulations $\left(300-400{ }^{\circ} \mathrm{C}\right)$ the oxidation efficiency of $\mathrm{CH}_{4}$ is low, thus a gas such as propane is more suitable and also typically available in most laboratories that do vehicle emissions testing (for calibration of other gas analyzers).

\subsubsection{Catalytic Stripper Technical Requirements}

Table 3 gives suggestions for future tests that could be required for the characterization of catalytic strippers (standalone or in a VPR system). Examples and citations where more details can be found are also given. Regarding particle losses, the requirements of the regulation should be fulfilled, i.e., $\mathrm{PCRF}_{15}$ to $\mathrm{PCRF}_{100}$ ratio $<2$. The wall temperature is also defined in the requirements, usually between $300{ }^{\circ} \mathrm{C}$ to $400{ }^{\circ} \mathrm{C}$. For catalytic strippers, it seems that the lower temperature limit is more advantageous because the $\mathrm{SO}_{2}$ to $\mathrm{SO}_{3}$ conversion is lower. This conversion ratio should be reported, especially for systems without a sulfur trap, which should have very low conversion. Systems with a sulfur trap should report the sulfur storage capacity. Two values should be reported: the complete (i.e., until no $\mathrm{SO}_{2}$ is measured downstream of the catalytic stripper) and the total (i.e., until the $\mathrm{SO}_{2}$ concentration at the outlet of the catalytic stripper is stabilized). The measurement of $\mathrm{SO}_{3}\left(\right.$ and $\left.\mathrm{H}_{2} \mathrm{SO}_{4}\right)$ is challenging. In the presence of water vapor in particular, sulfuric acid will be formed, that is corrosive and there are concerns regarding potential damage to the analytical equipment or even artefacts [81]. The particle removal efficiency should also be given. At the moment the preferred generation method is evaporation-condensation technique with tetracontane particles, as the atomization method of oils can result in residual particles from impurities in the atomized material. Even though the oxidation efficiency (e.g., of propane) is not so relevant for the specific application of catalytic strippers, it could be evaluated as a simple check of the long-term stability of the oxidation efficiency.

Table 3. Suggestions for technical requirements of catalytic strippers. The references give the experimental setups of the proposed tests. $\mathrm{HC}=$ hydrocarbons; VRE = volatile removal efficiency.

\begin{tabular}{cccc}
\hline Test & Comment & Example & Reference \\
\hline Particle losses & As required in the regulation & & {$[33,36]$} \\
Wall temperature & As required in the regulation & $300{ }^{\circ} \mathrm{C}$ to $350{ }^{\circ} \mathrm{C}$ & Regulation \\
$\mathrm{SO}_{2}$ to $\mathrm{SO}_{3}$ conversion & To be declared & $\%$ & {$[33,36]$} \\
$\mathrm{Sulfur}$ storage capacity & Based on $\mathrm{SO}_{2}$ & $\mathrm{mg}$ & {$[33,36]$} \\
VRE $\mathrm{H}_{2} \mathrm{SO}_{4}$ & Feasibility to be assessed & $>99.9 \% ;>1 \mathrm{mg} / \mathrm{m}^{3}$ & {$[39,44]$} \\
VRE gaseous HCs & Long term efficiency $\mathrm{C}_{3} \mathrm{H}_{8}$ & $>99.9 \% ;>10,000 \mathrm{ppm}$ & {$[33]$} \\
VRE particle $\mathrm{HCs}$ & Tetracontane particles & $>99.9 \% ;>1 \mathrm{mg} / \mathrm{m}^{3}$ & {$[30,33,36]$} \\
\hline
\end{tabular}

\section{Conclusions}

This review summarized the volatile removal efficiency of evaporation tubes (ET), thermodenuders (TD), and catalytic strippers (CS). Some of the catalytic strippers had only an oxidation part and some had, additionally, a sulfur trap upstream or downstream of the oxidation part.

Theoretically, CS oxidize the hydrocarbons resulting in smaller (if any) growth of any volatile nucleation mode particles, compared to evaporation tubes that reduce hydrocarbons only by dilution. CS with sulfur traps store sulfur compounds, thus, further minimizing any possibility of nucleating particles. On the other hand, if the sulfur trap is saturated, any existing $\mathrm{SO}_{3}$ or $\mathrm{SO}_{3}$ formed in the $\mathrm{CS}$ might enhance nucleation. At very high $\mathrm{SO}_{2}$ and/or $\mathrm{SO}_{3}$ concentrations the nucleated particles may grow to the measuring range of the instruments. Considering that modern vehicles emit some $\mathrm{SO}_{3}$ (and thus there is potential for nucleation) and the ET does not oxidize the hydrocarbons, the 
CS is a safer option for avoiding volatile artefacts (i.e., measuring re-nucleated volatile particles as non-volatiles).

The summary of the published experimental results showed that ET and TD could handle up to $2 \mathrm{mg} / \mathrm{m}^{3}$ of hydrocarbons without artefacts, but in some cases particles $<10 \mathrm{~nm}$ remained. Masses $>2 \mathrm{mg} / \mathrm{m}^{3}$ resulted in artefacts in the $10-23 \mathrm{~nm}$ range or even $>23 \mathrm{~nm}\left(15 \mathrm{mg} / \mathrm{m}^{3}\right)$ on some occasions. CS did not have any artefacts $>10 \mathrm{~nm}$ in any of the studies (with one exception that were presumably solid residuals). Inlet masses up to $13 \mathrm{~g} / \mathrm{m}^{3}$ could be handled with CS in most cases without any particles remaining, but in some cases particles $<10 \mathrm{~nm}$ were detected after CS even at hydrocarbon compound masses below $2 \mathrm{mg} / \mathrm{m}^{3}$.

With sulfuric acid containing aerosol, particles were always detected downstream of ET and TD: they were $<10 \mathrm{~nm}$ with $<0.2 \mathrm{mg} / \mathrm{m}^{3}$ upstream concentrations (with one exception of hot dilution and evaporation tube that could handle up to $2.5 \mathrm{mg} / \mathrm{m}^{3}$ ). The CS could efficiently handle the sulfuric acid aerosol. However, at concentrations $>1 \mathrm{mg} / \mathrm{m}^{3}$ some particles below $10 \mathrm{~nm}$ remained. The limited data show that with a sulfur trap higher masses can be handled. In two cases, CS with a sulfur trap could handle at least $9 \mathrm{mg} / \mathrm{m}^{3}$ without any particles remaining.

The vehicle exhaust aerosol had remaining particles larger than $10 \mathrm{~nm}$ for masses $>0.5 \mathrm{mg} / \mathrm{m}^{3}$ and $<10 \mathrm{~nm}$ even for masses of $0.05 \mathrm{mg} / \mathrm{m}^{3}$ for the ET systems. The CS had no cases with remaining particles $>10 \mathrm{~nm}$. There were cases with particles $<10 \mathrm{~nm}$ when the mass was $0.65 \mathrm{mg} / \mathrm{m}^{3}$ (standalone) or $50 \mathrm{mg} / \mathrm{m}^{3}$ (downstream of hot dilution).

In general, the experimental results of the reviewed studies showed that the CS is the safest option for minimum artefacts for measurements $>10 \mathrm{~nm}$. Studies below $10 \mathrm{~nm}$ still need attention, even with CS, both regarding the volatile removal efficiency, but also the high particle losses. The above results also confirm that the CS should be allowed in place or in addition to the ET of the existing systems measuring $>23 \mathrm{~nm}$.

Due to the substantial variability of the results and the different removal efficiencies of the various systems, in order to standardize the evaluation of the systems, it is recommended to include a volatile removal efficiency test. Realistic levels of challenge aerosol should be in the order of $1 \mathrm{mg} / \mathrm{m}^{3}$ (except mopeds that exceed $10 \mathrm{mg} / \mathrm{m}^{3}$ ). At the moment, it is not clear what is a representative chemical composition of the volatile particles, but it seems that sulfuric acid plays a major role in their formation and should also be included in the volatile removal assessment of the systems. However, $\mathrm{H}_{2} \mathrm{SO}_{4}$ is corrosive and there are concerns regarding potential damage to the analytical equipment or even artefacts. Catalytic strippers with sulfur traps should report their storage capacity and those without, should confirm that no (or minimum) $\mathrm{SO}_{2}$ to $\mathrm{SO}_{3}$ conversion takes place.

Author Contributions: Conceptualization, B.G.; formal analysis, B.G.; writing-original draft preparation, B.G. and A.D.M.; writing-review and editing, T.L. and G.M.; All authors have read and agreed to the published version of the manuscript.

Funding: This research received no external funding.

Acknowledgments: The authors would like to acknowledge the comments of A. Mamakos and Y. Otsuki at earlier draft versions. B.G. appreciates the discussions with L. Ntziachristos.

Conflicts of Interest: The authors declare no conflict of interest.

\section{References}

1. Giechaskiel, B.; Maricq, M.; Ntziachristos, L.; Dardiotis, C.; Wang, X.; Axmann, H.; Bergmann, A.; Schindler, W. Review of motor vehicle particulate emissions sampling and measurement: From smoke and filter mass to particle number. J. Aerosol Sci. 2014, 67, 48-86. [CrossRef]

2. Giechaskiel, B.; Mamakos, A.; Andersson, J.; Dilara, P.; Martini, G.; Schindler, W.; Bergmann, A. Measurement of automotive nonvolatile particle number emissions within the European legislative framework: A review. Aerosol Sci. Technol. 2012, 46, 719-749. [CrossRef] 
3. Giechaskiel, B.; Lähde, T.; Suarez-Bertoa, R.; Clairotte, M.; Grigoratos, T.; Zardini, A.; Perujo, A.; Martini, G. Particle number measurements in the European legislation and future JRC activities. Combust. Engines 2018, 174, 3-16. [CrossRef]

4. Giechaskiel, B.; Joshi, A.; Ntziachristos, L.; Dilara, P. European regulatory framework and particulate matter emissions of gasoline light-duty vehicles: A review. Catalysts 2019, 9, 586. [CrossRef]

5. Giechaskiel, B.; Drossinos, Y. Theoretical investigation of volatile removal efficiency of particle number measurement systems. SAE Int. J. Engines 2010, 3, 1140-1151. [CrossRef]

6. Burtscher, H. Physical characterization of particulate emissions from diesel engines: A review. J. Aerosol Sci. 2005, 36, 896-932. [CrossRef]

7. Giechaskiel, B.; Bonnel, P.; Perujo, A.; Dilara, P. Solid particle number (SPN) portable emissions measurement systems (PEMS) in the European legislation: A review. IJERPH 2019, 16, 4819. [CrossRef]

8. Giechaskiel, B.; Vanhanen, J.; Väkevä, M.; Martini, G. Investigation of vehicle exhaust sub-23 nm particle emissions. Aerosol Sci. Technol. 2017, 51, 626-641. [CrossRef]

9. Johnson, K.C.; Durbin, T.D.; Jung, H.; Chaudhary, A.; Cocker, D.R.; Herner, J.D.; Robertson, W.H.; Huai, T.; Ayala, A.; Kittelson, D. Evaluation of the European PMP methodologies during on-road and chassis dynamometer testing for dpf equipped heavy-duty diesel vehicles. Aerosol Sci. Technol. 2009, 43, 962-969. [CrossRef]

10. Giechaskiel, B.; Manfredi, U.; Martini, G. Engine exhaust solid sub-23 nm particles: I. literature survey. SAE Int. J. Fuels Lubr. 2014, 7, 950-964. [CrossRef]

11. Rönkkö, T.; Virtanen, A.; Kannosto, J.; Keskinen, J.; Lappi, M.; Pirjola, L. Nucleation mode particles with a nonvolatile core in the exhaust of a heavy duty diesel vehicle. Environ. Sci. Technol. 2007, 41, 6384-6389. [CrossRef]

12. Giechaskiel, B. Solid particle number emission factors of Euro VI heavy-duty vehicles on the road and in the laboratory. IJERPH 2018, 15, 304. [CrossRef] [PubMed]

13. Mayer, A.; Czerwinski, J.; Kasper, M.; Ulrich, A.; Mooney, J.J. Metal Oxide Particle Emissions from Diesel and Petrol Engines; SAE: Warrendale, PA, USA, 2012.

14. Giechaskiel, B.; Martini, G. Engine exhaust solid sub-23 nm particles: II feasibility study for particle number measurement systems. SAE Int. J. Fuels Lubr. 2014, 7, 935-949. [CrossRef]

15. Giechaskiel, B.; Mamakos, A.; Woodburn, J.; Szczotka, A.; Bielaczyc, P. Evaluation of a $10 \mathrm{~nm}$ particle number portable emissions measurement system (PEMS). Sensors 2019, 19, 5531. [CrossRef] [PubMed]

16. Giechaskiel, B.; Lähde, T.; Gandi, S.; Keller, S.; Kreutziger, P.; Mamakos, A. Assessment of 10-nm particle number (PN) portable emissions measurement systems (PEMS) for future regulations. IJERPH 2020, 17, 3878. [CrossRef] [PubMed]

17. Abdul-Khalek, I.S.; Kittelson, D.B. Real time measurement of volatile and solid exhaust particles using a catalytic stripper. SAE Trans. 1995, 104, 462-478. [CrossRef]

18. Twigg, M.V. Catalytic control of emissions from cars. Catal. Today 2011, 163, 33-41. [CrossRef]

19. Roy, S.; Baiker, A. NOx storage-reduction catalysis: From mechanism and materials properties to storage-reduction performance. Chem. Rev. 2009, 109, 4054-4091. [CrossRef]

20. Liu, G.; Gao, P.-X. A review of NOx storage/reduction catalysts: Mechanism, materials and degradation studies. Catal. Sci. Technol. 2011, 1, 552-568. [CrossRef]

21. Xu, F.; Chen, L.; Stone, R. Effects of a catalytic volatile particle remover (VPR) on the particulate matter emissions from a direct injection spark ignition engine. Environ. Sci. Technol. 2011, 45, 9036-9043. [CrossRef]

22. Lobo, P.; Durdina, L.; Brem, B.T.; Crayford, A.P.; Johnson, M.P.; Smallwood, G.J.; Siegerist, F.; Williams, P.I.; Black, E.A.; Llamedo, A.; et al. Comparison of standardized sampling and measurement reference systems for aircraft engine non-volatile particulate matter emissions. J. Aerosol Sci. 2020, 145, 105557. [CrossRef]

23. Lin, Y.; Bahreini, R.; Zimmerman, S.; Fofie, E.A.; Asa-Awuku, A.; Park, K.; Lee, S.-B.; Bae, G.-N.; Jung, H.S. Investigation of ambient aerosol effective density with and without using a catalytic stripper. Atmos. Environ. 2018, 187, 84-92. [CrossRef]

24. Burtscher, H.; Baltensperger, U.; Bukowiecki, N.; Cohn, P.; Hüglin, C.; Mohr, M.; Matter, U.; Nyeki, S.; Schmatloch, V.; Streit, N.; et al. Separation of volatile and non-volatile aerosol fractions by thermodesorption: Instrumental development and applications. J. Aerosol Sci. 2001, 32, 427-442. [CrossRef] 
25. Huffman, J.A.; Ziemann, P.J.; Jayne, J.T.; Worsnop, D.R.; Jimenez, J.L. Development and characterization of a fast-stepping/scanning thermodenuder for chemically-resolved aerosol volatility measurements. Aerosol Sci. Technol. 2008, 42, 395-407. [CrossRef]

26. Donahue, N.M.; Kroll, J.H.; Pandis, S.N.; Robinson, A.L. A two-dimensional volatility basis set-Part 2: Diagnostics of organic-aerosol evolution. Atmos. Chem. Phys. 2012, 12, 615-634. [CrossRef]

27. Maricq, M.M. Chemical characterization of particulate emissions from diesel engines: A review. J. Aerosol Sci. 2007, 38, 1079-1118. [CrossRef]

28. Choi, S.; Myung, C.L.; Park, S. Review on characterization of nano-particle emissions and PM morphology from internal combustion engines: Part 2. Int. J. Autom. Technol. 2014, 15, 219-227. [CrossRef]

29. Khalek, I.A. Sampling system for solid and volatile exhaust particle size, number, and mass emissions. SAE Trans. 2007, 116, 122-133. [CrossRef]

30. Khalek, I.A.; Bougher, T. Development of a solid exhaust particle number measurement system using a catalytic stripper technology. SAE Int. J. Engines 2011, 4, 610-618. [CrossRef]

31. Kittelson, D.B.; Stenitzer, M. A new catalytic stripper for removal of volatile particles. In Proceedings of the 7th ETH Conference on Combustion Generated Nanoparticles, Zurich, Switzerland, 18-20 August 2003.

32. Swanson, J.; Kittelson, D. Evaluation of thermal denuder and catalytic stripper methods for solid particle measurements. J. Aerosol Sci. 2010, 41, 1113-1122. [CrossRef]

33. Amanatidis, S.; Ntziachristos, L.; Giechaskiel, B.; Katsaounis, D.; Samaras, Z.; Bergmann, A. Evaluation of an oxidation catalyst ("catalytic stripper") in eliminating volatile material from combustion aerosol. J. Aerosol Sci. 2013, 57, 144-155. [CrossRef]

34. Giechaskiel, B.; Zardini, A.; Martini, G. Particle emission measurements from L-category vehicles. SAE Int. J. Engines 2015, 8, 2322-2337. [CrossRef]

35. Amanatidis, S.; Ntziachristos, L.; Karjalainen, P.; Saukko, E.; Simonen, P.; Kuittinen, N.; Aakko-Saksa, P.; Timonen, H.; Rönkkö, T.; Keskinen, J. Comparative performance of a thermal denuder and a catalytic stripper in sampling laboratory and marine exhaust aerosols. Aerosol Sci. Technol. 2018, 52, 420-432. [CrossRef]

36. Melas, A.D.; Koidi, V.; Deloglou, D.; Daskalos, E.; Zarvalis, D.; Papaioannou, E.; Konstandopoulos, A.G. Development and evaluation of a catalytic stripper for the measurement of solid ultrafine particle emissions from internal combustion engines. Aerosol Sci. Technol. 2020, 54, 704-714. [CrossRef]

37. Giechaskiel, B.; Riccobono, F.; Bonnel, P. Feasibility Study on the Extension of the Real-Driving Emissions (RDE) Procedure to Particle Number (PN): Chassis Dynamometer Evaluation of Portable Emission Measurement Systems (PEMS) to Measure Particle Number (PN) Concentration: Phase II; Publications Office: Luxembourg, 2015; ISBN 978-92-79-51003-8.

38. Otsuki, Y.; Tochino, S.; Kondo, K.; Haruta, K. Portable Emissions Measurement System for Solid Particle Number Including Nanoparticles Smaller than 23 nm; SAE International: Warrendale, PA, USA, 2017.

39. Otsuki, Y.; Takeda, K.; Haruta, K.; Mori, N. A Solid Particle Number Measurement System Including Nanoparticles Smaller than 23 Nanometers; SAE International: Warrendale, PA, USA, 2014.

40. Kiwull, B.; Wolf, J.C.; Niessner, R. Evaluation of Volatile Particle Remover Devices for Exhaust Particle Quantification; Technische Universität München: Munich, Germany, 2015.

41. Zheng, Z.; Johnson, K.C.; Liu, Z.; Durbin, T.D.; Hu, S.; Huai, T.; Kittelson, D.B.; Jung, H.S. Investigation of Solid Particle Number Measurement: Existence and Nature of Sub-23nm Particles Under PMP Methodology. J. Aerosol Sci. 2011, 42, 883-897. [CrossRef]

42. Kasper, M. Characterisation of the Second Generation PMP "Golden Instrument"; SAE International: Warrendale, PA, USA, 2008.

43. Giechaskiel, B.; Carriero, M.; Martini, G.; Krasenbrink, A.; Scheder, D. Calibration and validation of various commercial particle number measurement systems. SAE Int. J. Fuels Lubr. 2009, 2, 512-530. [CrossRef]

44. Swanson, J.; Kittelson, D.; Giechaskiel, B.; Bergmann, A.; Twigg, M. A miniature catalytic stripper for particles less than 23 nanometers. SAE Int. J. Fuels Lubr. 2013, 6, 542-551. [CrossRef]

45. Emery Oil Removal Efficiency. Available online: http://catalytic-instruments.com/wp-content/uploads/2019/ 09/Application-note0007.pdf (accessed on 24 June 2020).

46. Crayford, A.P.; Johnson, M.; Marsh, R.; Sevcenco, Y.; Walters, D.; Williams, P.; Christie, S.; Chung, W.; Petzold, A.; Ibrahim, A.; et al. SAMPLE III (SC01): Contribution to Aircraft Engine PM Certification Requirement and Standard First Specific Contract_Final Report; EASA: Cologne, Germany, 2011. 
47. Kim, S.; Kondo, K.; Otsuki, Y.; Haruta, K. A New On-Board PN Analyzer for Monitoring the Real-Driving Condition; SAE International: Warrendale, PA, USA, 2017.

48. Ho, J.; Kournikakis, B.; Gunning, A.; Fildes, J. Submicron aerosol characterization of water by a differential mobility particle sizer. J. Aerosol Sci. 1988, 19, 1425-1428. [CrossRef]

49. Giechaskiel, B.; Chirico, R.; DeCarlo, P.F.; Clairotte, M.; Adam, T.; Martini, G.; Heringa, M.F.; Richter, R.; Prevot, A.S.H.; Baltensperger, U. Evaluation of the particle measurement programme (PMP) protocol to remove the vehicles' exhaust aerosol volatile phase. Sci. Total Environ. 2010, 408, 5106-5116. [CrossRef]

50. Giechaskiel, B. Differences between tailpipe and dilution tunnel sub-23 nm nonvolatile (solid) particle number measurements. Aerosol Sci. Technol. 2019, 53, 1012-1022. [CrossRef]

51. Mamakos, A.; Martini, G.; Marotta, A.; Manfredi, U. Assessment of different technical options in reducing particle emissions from gasoline direct injection vehicles. J. Aerosol Sci. 2013, 63, 115-125. [CrossRef]

52. Ntziachristos, L.; Amanatidis, S.; Samaras, Z.; Giechaskiel, B.; Bergmann, A. Use of a catalytic stripper as an alternative to the original PMP measurement protocol. SAE Int. J. Fuels Lubr. 2013, 6, 532-541. [CrossRef]

53. Mamakos, A.; Martini, G.; Manfredi, U. Assessment of the legislated particle number measurement procedure for a Euro 5 and a Euro 6 compliant diesel passenger cars under regulated and unregulated conditions. J. Aerosol Sci. 2013, 55, 31-47. [CrossRef]

54. Giechaskiel, B.; Riccobono, F.; Mendoza-Villafuerte, P.; Grigoratos, T. Particle Number (PN)—Portable Emissions Measurement Systems (PEMS) Heavy Duty Vehicles Evaluation Phase at the Joint Research Centre (JRC); Publications Office: Luxembourg, 2016.

55. Zheng, Z.; Durbin, T.D.; Karavalakis, G.; Johnson, K.C.; Chaudhary, A.; Cocker, D.R.; Herner, J.D.; Robertson, W.H.; Huai, T.; Ayala, A.; et al. Nature of sub-23-nm particles downstream of the European particle measurement programme (PMP)-compliant system: A real-time data perspective. Aerosol Sci. Technol. 2012, 46, 886-896. [CrossRef]

56. Ntziachristos, L.; Giechaskiel, B.; Pistikopoulos, P.; Samaras, Z. Comparative Assessment of Two Different Sampling Systems for Particle Emission Type-Approval Measurements; SAE International: Warrendale, PA, USA, 2005.

57. Giechaskiel, B. Particle number emissions of a diesel vehicle during and between regeneration events. Catalysts 2020. [CrossRef]

58. Yu, F. Effect of ammonia on new particle formation: A kinetic $\mathrm{H}_{2} \mathrm{SO}_{4}-\mathrm{H}_{2} \mathrm{O}-\mathrm{NH}_{3}$ nucleation model constrained by laboratory measurements. J. Geophys. Res. 2006, 111. [CrossRef]

59. Lemmetty, M.; Vehkamäki, H.; Virtanen, A.; Kulmala, M.; Keskinen, J. Homogeneous ternary $\mathrm{H}_{2} \mathrm{SO}_{4}-\mathrm{NH}_{3}-\mathrm{H}_{2} \mathrm{O}$ nucleation and diesel exhaust: A classical approach. Aerosol Air Qual. Res. 2007, 7, 489-499. [CrossRef]

60. Benson, D.R.; Yu, J.H.; Markovich, A.; Lee, S.-H. Ternary homogeneous nucleation of $\mathrm{H}_{2} \mathrm{SO}_{4}, \mathrm{NH}_{3}$, and $\mathrm{H}_{2} \mathrm{O}$ under conditions relevant to the lower troposphere. Atmos. Chem. Phys. 2011, 11, 4755-4766. [CrossRef]

61. Suarez-Bertoa, R.; Pechout, M.; Vojtíšek, M.; Astorga, C. Regulated and non-regulated emissions from Euro 6 diesel, gasoline and CNG vehicles under real-world driving conditions. Atmosphere 2020, 11, 204. [CrossRef]

62. Czerwinski, J.; Zimmerli, Y.; Mayer, A.; Heeb, N.; Lemaire, J.; D’Urbano, G.; Bunge, R. Testing of Combined DPF+SCR Systems for HD-Retrofitting-VERTdePN; SAE International: Warrendale, PA, USA, 2009.

63. Sipila, M.; Berndt, T.; Petaja, T.; Brus, D.; Vanhanen, J.; Stratmann, F.; Patokoski, J.; Mauldin, R.L.; Hyvarinen, A.-P.; Lihavainen, H.; et al. The role of sulfuric acid in atmospheric nucleation. Science 2010, 327, 1243-1246. [CrossRef]

64. Uhrner, U.; von Löwis, S.; Vehkamäki, H.; Wehner, B.; Bräsel, S.; Hermann, M.; Stratmann, F.; Kulmala, M.; Wiedensohler, A. Dilution and aerosol dynamics within a diesel car exhaust plume-CFD simulations of on-road measurement conditions. Atmos. Environ. 2007, 41, 7440-7461. [CrossRef]

65. Olin, M.; Alanen, J.; Palmroth, M.R.T.; Rönkkö, T.; Dal Maso, M. Inversely modeling homogeneous $\mathrm{H}_{2} \mathrm{SO}_{4}-\mathrm{H}_{2} \mathrm{O}$ nucleation rate in exhaust-related conditions. Atmos. Chem. Phys. 2019, 19, 6367-6388. [CrossRef]

66. Karjalainen, P.; Rönkkö, T.; Pirjola, L.; Heikkilä, J.; Happonen, M.; Arnold, F.; Rothe, D.; Bielaczyc, P.; Keskinen, J. Sulfur driven nucleation mode formation in diesel exhaust under transient driving conditions. Environ. Sci. Technol. 2014, 2336-2343. [CrossRef] [PubMed]

67. Du, H.; Yu, F. Nanoparticle formation in the exhaust of vehicles running on ultra-low sulfur fuel. Atmos. Chem. Phys. 2008, 8, 4729-4739. [CrossRef] 
68. Vaaraslahti, K.; Keskinen, J.; Giechaskiel, B.; Solla, A.; Murtonen, T.; Vesala, H. Effect of lubricant on the formation of heavy-duty diesel exhaust nanoparticles. Environ. Sci. Technol. 2005, 39, 8497-8504. [CrossRef]

69. Lemmetty, M.; Rönkkö, T.; Virtanen, A.; Keskinen, J.; Pirjola, L. The effect of sulphur in diesel exhaust aerosol: Models compared with measurements. Aerosol Sci. Technol. 2008, 42, 916-929. [CrossRef]

70. Khalek, I.A.; Kittelson, D.B.; Brear, F. Nanoparticle Growth During Dilution and Cooling of Diesel Exhaust: Experimental Investigation and Theoretical Assessment; SAE International: Warrendale, PA, USA, 2000.

71. Arnold, F.; Pirjola, L.; Rönkkö, T.; Reichl, U.; Schlager, H.; Lähde, T.; Heikkilä, J.; Keskinen, J. First online measurements of sulfuric acid gas in modern heavy-duty diesel engine exhaust: Implications for nanoparticle formation. Environ. Sci. Technol. 2012, 46, 11227-11234. [CrossRef]

72. Vouitsis, E.; Ntziachristos, L.; Samaras, Z. Modelling of diesel exhaust aerosol during laboratory sampling. Atmos. Environ. 2005, 39, 1335-1345. [CrossRef]

73. Vouitsis, E.; Ntziachristos, L.; Samaras, Z. Theoretical investigation of the nucleation mode formation downstream of diesel after-treatment devices. Aerosol Air Qual. Res. 2008, 8, 37-53. [CrossRef]

74. Yamada, H.; Funato, K.; Sakurai, H. Application of the PMP methodology to the measurement of sub-23 nm solid particles: Calibration procedures, experimental uncertainties, and data correction methods. J. Aerosol Sci. 2015, 88, 58-71. [CrossRef]

75. Giechaskiel, B.; Martini, G. JRC sub-23 nm update. In Proceedings of the 37th PMP meeting, Brussels, Belgium, 7 October 2015.

76. AVL Comments on GTR15 Ammendment. Available online: https://wiki.unece.org/display/trans/PMP+ Web+Conference+02+April (accessed on 24 June 2020).

77. Neyestanaki, A.K.; Klingstedt, F.; Salmi, T.; Murzin, D.Y. Deactivation of postcombustion catalysts, a review. Fuel 2004, 83, 395-408. [CrossRef]

78. Giechaskiel, B.; Ntziachristos, L.; Samaras, Z.; Casati, R.; Scheer, V.; Vogt, R. Effect of Speed and Speed-Transition on the Formation of Nucleation Mode Particles from a Light Duty Diesel Vehicle; SAE International: Warrendale, PA, USA, 2007.

79. Cooper, B.J.; Thoss, J.E. Role of NO in diesel particulate emission control. SAE Trans. 1989, 98, 612-624. [CrossRef]

80. Kröcher, O.; Widmer, M.; Elsener, M.; Rothe, D. Adsorption and desorption of SOx on diesel oxidation catalysts. Ind. Eng. Chem. Res. 2009, 48, 9847-9857. [CrossRef]

81. Li, L.; King, D.L. Method for determining performance of sulfur oxide adsorbents for diesel emission control using online measurements of $\mathrm{SO}_{2}$ and $\mathrm{SO}_{3}$ in the effluent. Ind. Eng. Chem. Res. 2004, 43, 4452-4456. [CrossRef]

82. Koutsopoulos, S.; Rasmussen, S.B.; Eriksen, K.M.; Fehrmann, R. The role of support and promoter on the oxidation of sulfur dioxide using platinum based catalysts. Appl. Catal. A Gen. 2006, 306, 142-148. [CrossRef]

83. Xue, E.; Seshan, K.; van Ommen, J.G.; Ross, J.R.H. Catalytic control of diesel engine particulate emission: Studies on model reactions over a EuroPt-1 $\left(\mathrm{Pt} / \mathrm{SiO}_{2}\right)$ catalyst. Appl. Catal. B Environ. 1993, 2, $183-197$. [CrossRef]

84. Wyatt, M.; Manning, W.A.; Roth, S.A.; D'Aniello, M.J.; Andersson, E.S.; Fredholm, S.C.G. The design of flow-through diesel oxidation catalysts. SAE Trans. 1993, 102, 211-223. [CrossRef]

85. Horiuchi, M.; Saito, K.; Ichihara, S. The effects of flow-through type oxidation catalysts on the particulate reduction of 1990's diesel engines. SAE Trans. 1990, 99, 1268-1278. [CrossRef]

86. Hamzehlouyan, T.; Sampara, C.; Li, J.; Kumar, A.; Epling, W. Experimental and kinetic study of $\mathrm{SO}_{2}$ oxidation on a Pt $/ \gamma-\mathrm{Al}_{2} \mathrm{O}_{3}$ catalyst. Appl. Catal. B Environ. 2014, 152, 108-116. [CrossRef]

87. Koltsakis, G. Catalytic automotive exhaust aftertreatment. Prog. Energy Combust. Sci. 1997, $23,1-39$. [CrossRef]

88. Mathieu, Y.; Tzanis, L.; Soulard, M.; Patarin, J.; Vierling, M.; Molière, M. Adsorption of SOx by oxide materials: A review. Fuel Process. Technol. 2013, 114, 81-100. [CrossRef]

89. Smedler, G.; Ahlström, G.; Fredholm, S.; Frost, J.; Lööf, P.; Marsh, P.; Walker, A.; Winterborn, D. High Performance Diesel Catalysts for Europe Beyond 1996; SAE International: Warrendale, PA, USA, 1995.

90. Henk, M.G.; Williamson, W.B.; Silver, R.G. Diesel Catalysts for Low Particulate and Low Sulfate Emissions; SAE International: Warrendale, PA, USA, 1992.

91. Lampert, J.; Kazi, M.; Farrauto, R. Palladium catalyst performance for methane emissions abatement from lean burn natural gas vehicles. Appl. Catal. B Environ. 1997, 14, 211-223. [CrossRef] 
92. Kärkkäinen, M.; Honkanen, M.; Viitanen, V.; Kolli, T.; Valtanen, A.; Huuhtanen, M.; Kallinen, K.; Vippola, M.; Lepistö, T.; Lahtinen, J.; et al. Deactivation of diesel oxidation catalysts by sulphur in laboratory and engine-bench scale aging. Top Catal. 2013, 56, 672-678. [CrossRef]

93. Taylor, K.C. Sulfur storage on automotive catalysts. Ind. Eng. Chem. Prod. Res. Dev. 1976, 15, $264-268$. [CrossRef]

94. Wang, Q.; Zhu, J.; Wei, S.; Chung, J.S.; Guo, Z. Sulfur poisoning and regeneration of NOx storage-reduction $\mathrm{Cu} / \mathrm{K} 2 \mathrm{Ti2O} 5$ catalyst. Ind. Eng. Chem. Res. 2010, 49, 7330-7335. [CrossRef]

95. Liu, X.; Chen, L.; Qi, G. Enhanced $\mathrm{SO}_{2}$ capture performance of $\mathrm{MnO} 2$ by doping with alkali metal ions for diesel emission control. Chem. Eng. Technol. 2018, 41, 1675-1681. [CrossRef]

96. Li, L.; King, D.L. High-capacity sulfur dioxide absorbents for diesel emissions control. Ind. Eng. Chem. Res. 2005, 44, 168-177. [CrossRef]

97. Horiuchi, M.; Saito, K.; Ichihara, S. Sulfur Storage and Discharge Behavior on Flow-Through Type Oxidation Catalysts; SAE International: Warrendale, PA, USA, 1991.

98. Centi, G.; Passarini, N.; Perathoner, S.; Riva, A. Combined DeSOx/DeNOx reactions on a copper on alumina sorbent-catalyst. 1. Mechanism of sulfur dioxide oxidation-adsorption. Ind. Eng. Chem. Res. 1992, 31, 1947-1955. [CrossRef]

99. Limousy, L.; Mahzoul, H.; Brilhac, J.F.; Gilot, P.; Garin, F.; Maire, G. $\mathrm{SO}_{2}$ sorption on fresh and aged SOx traps. Appl. Catal. B Environ. 2003, 42, 237-249. [CrossRef]

100. Dawody, J.; Skoglundh, M.; Olsson, L.; Fridell, E. Sulfur deactivation of $\mathrm{Pt} / \mathrm{SiO}_{2}, \mathrm{Pt} / \mathrm{BaO} / \mathrm{Al}_{2} \mathrm{O}_{3}$, and $\mathrm{BaO} / \mathrm{Al}_{2} \mathrm{O}_{3} \mathrm{NOx}$ storage catalysts: Influence of $\mathrm{SO}_{2}$ exposure conditions. J. Catal. 2005, 234, 206-218. [CrossRef]

101. Dawody, J.; Skoglundh, M.; Olsson, L.; Fridell, E. Kinetic modelling of sulfur deactivation of $\mathrm{Pt} / \mathrm{BaO} / \mathrm{Al}_{2} \mathrm{O}_{3}$ and $\mathrm{BaO} / \mathrm{Al}_{2} \mathrm{O}_{3} \mathrm{NOx}$ storage catalysts. Appl. Catal. B Environ. 2007, 70, 179-188. [CrossRef]

102. Kylhammar, L.; Carlsson, P.-A.; Ingelsten, H.H.; Grönbeck, H.; Skoglundh, M. Regenerable ceria-based SOx traps for sulfur removal in lean exhausts. Appl. Catal. B Environ. 2008, 84, 268-276. [CrossRef]

103. Hamzehlouyan, T.; Sampara, C.S.; Li, J.; Kumar, A.; Epling, W.S. Kinetic study of adsorption and desorption of $\mathrm{SO}_{2}$ over $\gamma-\mathrm{Al}_{2} \mathrm{O}_{3}$ and $\mathrm{Pt} / \gamma-\mathrm{Al}_{2} \mathrm{O}_{3}$. Appl. Catal. B Environ. 2016, 181, 587-598. [CrossRef]

104. Yoshida, K.; Asanuma, T.; Nishioka, H.; Hayashi, K.; Hirota, S. Development of NOx Reduction System for Diesel Aftertreatment with Sulfur Trap Catalyst; SAE International: Warrendale, PA, USA, 2007.

105. Englund, J.; Xie, K.; Dahlin, S.; Schaefer, A.; Jing, D.; Shwan, S.; Andersson, L.; Carlsson, P.-A.; Pettersson, L.J.; Skoglundh, M. Deactivation of a Pd/Pt bimetallic oxidation catalyst used in a biogas-powered Euro VI heavy-duty engine installation. Catalysts 2019, 9, 1014. [CrossRef]

106. Argyle, M.; Bartholomew, C. Heterogeneous catalyst deactivation and regeneration: A review. Catalysts 2015, 5, 145-269. [CrossRef]

107. Chasapidis, L.; Melas, A.D.; Tsakis, A.; Zarvalis, D.; Konstandopoulos, A. A Sampling and Conditioning Particle System for Solid Particle Measurements Down to $10 \mathrm{~nm}$; SAE International: Warrendale, PA, USA, 2019.

108. Miller, J.; Jin, L. Global Progress toward Soot-Free Diesel Vehicles; International Council Clean Transportation (ICCT) Report; ICCT: Washington, DC, USA, 2019.

109. Yamada, H.; Inomata, S.; Tanimoto, H. Mechanisms of increased particle and VOC emissions during DPF active regeneration and practical emissions considering regeneration. Environ. Sci. Technol. 2017, 51, 2914-2923. [CrossRef] [PubMed]

110. Yasar, A.; Haider, R.; Tabinda, A.B.; Kausar, F.; Khan, M. A comparison of engine emissions from heavy, medium, and light vehicles for CNG, diesel, and gasoline fuels. Pol. J. Environ. Stud. 2013, 22, 1277-1281.

111. Tavares, J.R.; Sthel, M.S.; Campos, L.S.; Rocha, M.V.; Lima, G.R.; da Silva, M.G.; Vargas, H. Evaluation of pollutant gases emitted by ethanol and gasoline powered vehicles. Proc. Environ. Sci. 2011, 4, 51-60. [CrossRef]

112. Gentner, D.R.; Worton, D.R.; Isaacman, G.; Davis, L.C.; Dallmann, T.R.; Wood, E.C.; Herndon, S.C.; Goldstein, A.H.; Harley, R.A. Chemical composition of gas-phase organic carbon emissions from motor vehicles and implications for ozone production. Environ. Sci. Technol. 2013, 47, 11837-11848. [CrossRef]

113. Tobias, H.J.; Beving, D.E.; Ziemann, P.J.; Sakurai, H.; Zuk, M.; McMurry, P.H.; Zarling, D.; Waytulonis, R.; Kittelson, D.B. Chemical analysis of diesel engine nanoparticles using a nano-DMA/thermal desorption particle beam mass spectrometer. Environ. Sci. Technol. 2001, 35, 2233-2243. [CrossRef] 
114. Sakurai, H.; Tobias, H.J.; Park, K.; Zarling, D.; Docherty, K.S.; Kittelson, D.B.; McMurry, P.H.; Ziemann, P.J. On-line measurements of diesel nanoparticle composition and volatility. Atmos. Environ. 2003, 37, 1199-1210. [CrossRef]

115. Swanson, J.J.; Kittelson, D.B.; Watts, W.F.; Gladis, D.D.; Twigg, M.V. Influence of storage and release on particle emissions from new and used CRTs. Atmos. Environ. 2009, 43, 3998-4004. [CrossRef]

116. Schneider, J.; Hock, N.; Weimer, S.; Borrmann, S.; Kirchner, U.; Vogt, R.; Scheer, V. Nucleation particles in diesel exhaust: Composition inferred from in situ mass spectrometric analysis. Environ. Sci. Technol. 2005, 39, 6153-6161. [CrossRef]

117. Karavalakis, G.; Gysel, N.; Schmitz, D.A.; Cho, A.K.; Sioutas, C.; Schauer, J.J.; Cocker, D.R.; Durbin, T.D. Impact of biodiesel on regulated and unregulated emissions, and redox and proinflammatory properties of PM emitted from heavy-duty vehicles. Sci. Total Environ. 2017, 584, 1230-1238. [CrossRef]

118. Alves, C.A.; Lopes, D.J.; Calvo, A.I.; Evtyugina, M.; Rocha, S.; Nunes, T. Emissions from light-duty diesel and gasoline in-use vehicles measured on chassis dynamometer test cycles. Aerosol Air Qual. Res. 2015, 15, 99-116. [CrossRef]

119. Tsai, J.-H.; Huang, P.-H.; Chiang, H.-L. Air pollutants and toxic emissions of various mileage motorcycles for ECE driving cycles. Atmos. Environ. 2017, 153, 126-134. [CrossRef]

120. Ntziachristos, L.; Vonk, W.A.; Papadopoulos, G.; van Mensch, P.; Geivanidis, S.; Mellios, G.; Papadimitriou, G.; Steven, H.; Elstgeest, M.; Ligterink, N.E.; et al. Effect Study of the Environmental Step Euro 5 for L-Category Vehicles; European Commission: Brussels, Belgium, 2017; ISBN 978-92-79-70203-7.

121. Kontses, A.; Ntziachristos, L.; Zardini, A.A.; Papadopoulos, G.; Giechaskiel, B. Particulate emissions from L-Category vehicles towards Euro 5. Environ. Res. 2020, 182, 109071. [CrossRef]

122. Costagliola, M.A.; Murena, F.; Prati, M.V. Exhaust emissions of volatile organic compounds of powered two-wheelers: Effect of cold start and vehicle speed. Contribution to greenhouse effect and tropospheric ozone formation. Sci. Total Environ. 2014, 468, 1043-1049. [CrossRef]

123. Liu, X.; Deng, B.; Fu, J.; Xu, Z.; Liu, J.; Li, M.; Li, Q.; Ma, Z.; Feng, R. The effect of air/fuel composition on the HC emissions for a twin-spark motorcycle gasoline engine: A wide condition range study. Chem. Eng. J. 2019, 355, 170-180. [CrossRef]

124. Szymlet, N.; Lijewski, P.; Sokolnicka, B.; Siedlecki, M.; Domowicz, A. Analysis of research method, results and regulations regarding the exhaust emissions from two-wheeled vehicles under actual operating conditions. J. Ecol. Eng. 2020, 21, 128-139. [CrossRef]

125. Kašpar, J.; Fornasiero, P.; Hickey, N. Automotive catalytic converters: Current status and some perspectives. Catal. Today 2003, 77, 419-449. [CrossRef]

126. Jaworski, A.; Mądziel, M.; Lejda, K. Creating an emission model based on portable emission measurement system for the purpose of a roundabout. Environ. Sci. Pollut. Res. 2019, 26, 21641-21654. [CrossRef]

127. Zhu, G.; Liu, J.; Fu, J.; Xu, Z.; Guo, Q.; Zhao, H. Experimental study on combustion and emission characteristics of turbocharged gasoline direct injection (GDI) engine under cold start new European driving cycle (NEDC). Fuel 2018, 215, 272-284. [CrossRef]

128. Yang, Z.; Liu, Y.; Wu, L.; Martinet, S.; Zhang, Y.; Andre, M.; Mao, H. Real-world gaseous emission characteristics of Euro $6 \mathrm{~b}$ light-duty gasoline- and diesel-fueled vehicles. Transp. Res. Part D Transp. Environ. 2020, 78, 102215. [CrossRef]

129. Ma, C.; Wu, L.; Mao, H.; Fang, X.; Wei, N.; Zhang, J.; Yang, Z.; Zhang, Y.; Lv, Z.; Yang, L. Transient characterization of automotive exhaust emission from different vehicle types based on on-road measurements. Atmosphere 2020, 11, 64. [CrossRef]

130. Simonen, P.; Kalliokoski, J.; Karjalainen, P.; Rönkkö, T.; Timonen, H.; Saarikoski, S.; Aurela, M.; Bloss, M.; Triantafyllopoulos, G.; Kontses, A.; et al. Characterization of laboratory and real driving emissions of individual Euro 6 light-duty vehicles-Fresh particles and secondary aerosol formation. Environ. Pollut. 2019, 255, 113175. [CrossRef]

131. Ko, J.; Son, J.; Myung, C.-L.; Park, S. Comparative study on low ambient temperature regulated/unregulated emissions characteristics of idling light-duty diesel vehicles at cold start and hot restart. Fuel 2018, 233, 620-631. [CrossRef]

132. Bikas, G.; Zervas, E. Regulated and non-regulated pollutants emitted during the regeneration of a diesel particulate filter. Energy Fuels 2007, 21, 1543-1547. [CrossRef] 
133. Jung, S.; Lim, J.; Kwon, S.; Jeon, S.; Kim, J.; Lee, J.; Kim, S. Characterization of particulate matter from diesel passenger cars tested on chassis dynamometers. J. Environ. Sci. 2017, 54, 21-32. [CrossRef]

134. R'Mili, B.; Boréave, A.; Meme, A.; Vernoux, P.; Leblanc, M.; Noël, L.; Raux, S.; D'Anna, B. Physico-chemical characterization of fine and ultrafine particles emitted during diesel particulate filter active regeneration of Euro 5 diesel vehicles. Environ. Sci. Technol. 2018, 52, 3312-3319. [CrossRef]

135. Ruehl, C.; Smith, J.D.; Ma, Y.; Shields, J.E.; Burnitzki, M.; Sobieralski, W.; Ianni, R.; Chernich, D.J.; Chang, M.-C.O.; Collins, J.F.; et al. Emissions during and real-world frequency of heavy-duty diesel particulate filter regeneration. Environ. Sci. Technol. 2018, 52, 5868-5874. [CrossRef] [PubMed]

136. Giechaskiel, B.; Gioria, R.; Carriero, M.; Lähde, T.; Forloni, F.; Perujo, A.; Martini, G.; Bissi, L.M.; Terenghi, R. Emission factors of a Euro VI heavy-duty diesel refuse collection vehicle. Sustainability 2019, 11, 1067. [CrossRef]

137. Doozandegan, M.; Hosseini, V.; Ehteram, M.A. Solid nanoparticle and gaseous emissions of a diesel engine with a diesel particulate filter and use of a high-sulphur diesel fuel and a medium-sulphur diesel fuel. Proc. Inst. Mech. Eng. Part. D J. Automob. Eng. 2017, 231, 941-951. [CrossRef]

138. Rothe, D.; Knauer, M.; Emmerling, G.; Deyerling, D.; Niessner, R. Emissions during active regeneration of a diesel particulate filter on a heavy duty diesel engine: Stationary tests. J. Aerosol Sci. 2015, 90, 14-25. [CrossRef]

139. Smith, J.D.; Ruehl, C.; Burnitzki, M.; Sobieralski, W.; Ianni, R.; Quiros, D.; Hu, S.; Chernich, D.; Collins, J.; Huai, T.; et al. Real-time particulate emissions rates from active and passive heavy-duty diesel particulate filter regeneration. Sci. Total Environ. 2019, 680, 132-139. [CrossRef] [PubMed]

(C) 2020 by the authors. Licensee MDPI, Basel, Switzerland. This article is an open access article distributed under the terms and conditions of the Creative Commons Attribution (CC BY) license (http://creativecommons.org/licenses/by/4.0/). 